\title{
Enhancing Mitochondrial Calcium Buffering Capacity Reduces Aggregation of Misfolded SOD1 and Motor Neuron Cell Death without Extending Survival in Mouse Models of Inherited Amyotrophic Lateral Sclerosis
}

\author{
Philippe A. Parone, ${ }^{\star}$ Sandrine Da Cruz, ${ }^{\star}$ Joo Seok Han, Melissa McAlonis-Downes, Anne P. Vetto, Sandra K. Lee, \\ Eva Tseng, and Don W. Cleveland \\ Ludwig Institute for Cancer Research and Department of Cellular and Molecular Medicine, University of California at San Diego, La Jolla, California 92093
}

\begin{abstract}
Mitochondria have been proposed as targets for toxicity in amyotrophic lateral sclerosis (ALS), a progressive, fatal adult-onset neurodegenerative disorder characterized by the selective loss of motor neurons. A decrease in the capacity of spinal cord mitochondria to buffer calcium $\left(\mathrm{Ca}^{2+}\right)$ has been observed in mice expressing ALS-linked mutants of SOD1 that develop motor neuron disease with many of the key pathological hallmarks seen in ALS patients. In mice expressing three different ALS-causing SOD1 mutants, we now test the contribution of the loss of mitochondrial $\mathrm{Ca}^{2+}$-buffering capacity to disease mechanism(s) by eliminating ubiquitous expression of cyclophilin D, a critical regulator of $\mathrm{Ca}^{2+}$-mediated opening of the mitochondrial permeability transition pore that determines mitochondrial $\mathrm{Ca}^{2+}$ content. A chronic increase in mitochondrial buffering of $\mathrm{Ca}^{2+}$ in the absence of cyclophilin $\mathrm{D}$ was maintained throughout disease course and was associated with improved mitochondrial ATP synthesis, reduced mitochondrial swelling, and retention of normal morphology. This was accompanied by an attenuation of glial activation, reduction in levels of misfolded SOD1 aggregates in the spinal cord, and a significant suppression of motor neuron death throughout disease. Despite this, muscle denervation, motor axon degeneration, and disease progression and survival were unaffected, thereby eliminating mutant SOD1-mediated loss of mitochondrial $\mathrm{Ca}^{2+}$ buffering capacity, altered mitochondrial morphology, motor neuron death, and misfolded SOD1 aggregates, as primary contributors to disease mechanism for fatal paralysis in these models of familial ALS.
\end{abstract}

\section{Introduction}

Amyotrophic lateral sclerosis (ALS) is an adult-onset neurodegenerative disease characterized by the selective loss of motor neurons (Boillée et al., 2006a). Twenty percent of inherited ALS is caused by mutations in $\mathrm{Cu} / \mathrm{Zn}$ superoxide dismutase (SOD1) (Rosen et al., 1993). At least nine mechanisms for mutant SOD1 toxicity have been proposed, including dysregulation of intracellular calcium homeostasis [especially from glutamate-mediated excitotoxicity (Rothstein et al., 1990, 1992)]; aggregation of misfolded mutant SOD1; and alterations in mitochondrial morphology, function, and distribution (Ilieva et al., 2009).

Received March 6, 2012; revised Dec. 18, 2012; accepted Dec. 20, 2012.

Author contributions: P.A.P., S.D.C., and D.W.C. designed research; P.A.P., S.D.C., J.S.H., M.M.-D., A.P.V., S.K.L., and E.T. performed research; P.A.P., S.D.C., and D.W.C. analyzed data; P.A.P., S.D.C., and D.W.C. wrote the paper.

This work has been supported by grants from the Muscular Dystrophy Association and the National Institutes of Health to D.W.C. S.D.C. was supported by a postdoctoral fellowship from the Amyotrophic Lateral Sclerosis Association. Salary support for D.W.C. is provided by the Ludwig Institute for Cancer Research. We are very grateful to Michael Forte and Paolo Bernardi for generously providing us with the $\mathrm{CypD}^{-1-}$ mice. We thank Neil Cashman and Jean-Pierre Julien for generously providing the misfolded SOD1 antibodies. We thank Timo Merloo and Ying Jones for their help with the electron microscopy study.

*P.A.P. and S.D.C. contributed equally to this work.

Correspondence should be addressed to Don W. Cleveland, Ludwig Institute and Department of Cellular and Molecular Medicine, University of California at San Diego, 9500 Gilman Drive, La Jolla, CA 92093-0670. E-mail: dcleveland@ucsd.edu.

DOI:10.1523/JNEUROSCI.1119-12.2013

Copyright $\odot 2013$ the authors $\quad 0270-6474 / 13 / 334657-15 \$ 15.00 / 0$
$\mathrm{Ca}^{2+}$-mediated excitotoxicity, following entry of $\mathrm{Ca}^{2+}$ through ionotropic glutamate receptors permeable to $\mathrm{Ca}^{2+}$, has been proposed as a critical component of ALS (Rothstein et al., 1990, 1992). Indeed, increased intracellular $\mathrm{Ca}^{2+}$ levels within motor neurons have been reported in patients (Siklós et al., 1996, 1998) and mouse models (von Lewinski et al., 2008; Jaiswal and Keller, 2009), as has decreased capacity of mitochondria to buffer $\mathrm{Ca}^{2+}$ (Damiano et al., 2006; Kawamata and Manfredi, 2010). Reducing cytosolic $\mathrm{Ca}^{2+}$ levels in motor neurons expressing mutant SOD1 in culture (Roy et al., 1998) and in mice has been reported to attenuate motor neuron death (Beers et al., 2001; Van Damme et al., 2003; Tateno et al., 2004; Van Den Bosch et al., 2006).

Mitochondria play a pivotal role in regulating $\mathrm{Ca}^{2+}$ levels (Nicholls, 2009). Indeed, a significant decrease in the $\mathrm{Ca}^{2+}$ loading capacity of mitochondria from spinal cords of mutant SOD1 transgenic mice has been reported to appear presymptomatically (Damiano et al., 2006). Mutant SOD1 is preferentially deposited on the surface of, or imported into, spinal cord mitochondria in mice that express ALS-linked mutants in SOD1 (Mattiazzi et al., 2002; Liu et al., 2004; Vijayvergiya et al., 2005; Bergemalm et al., 2006; Deng et al., 2006; Vande Velde et al., 2008), where it has been reported to interact with multiple components of the mitochondrial outer membrane and alters their activities (Israelson et al., 2010; Li et al., 2010; Pedrini et al., 2010). 
It is well accepted that irreversible opening of the mitochondrial permeability transition pore (MPTP), a nonselective high conductance channel located in the inner mitochondrial membrane (Azzolin et al., 2010), leads to mitochondrial depolarization, decreased ATP synthesis, matrix swelling, and mitochondrial degeneration (Hunter and Haworth, 1979; Bernardi, 1999; Petronilli et al., 2001; Bernardi et al., 2006). Genetic ablation of the gene encoding cyclophilin D (CypD) (named Ppif in mice) has demonstrated that CypD is a key regulator of $\mathrm{Ca}^{2+}$-induced opening of the MPTP. Mitochondria isolated from CypD-null animals store significantly increased quantities of $\mathrm{Ca}^{2+}$ before mPTP opening (Baines et al., 2005; Basso et al., 2005; Nakagawa et al., 2005; Schinzel et al., 2005; Barsukova et al., 2011).

By eliminating CypD expression in each of the three most prominently used mouse models of familial ALS from expression of ALS-causing mutants of SOD1 of divergent biochemical properties, we have now tested whether rescuing the loss of mitochondrial $\mathrm{Ca}^{2+}$ buffering capacity throughout disease can alter ALS-like pathogenesis.

\section{Materials and Methods}

Animals. All mouse lines were on a pure C57BI/6 background: cyclophilin D-null mice with ubiquitous deletion of the Ppif gene, which encodes the cyclophilin D protein (Basso et al., 2005) and ALS mice [SOD1 ${ }^{\text {G93A, }}$ SOD1 G85R, and SOD1 ${ }^{\text {G37R }}$ (Gurney et al., 1994; Bruijn et al., 1997; Boillée et al., 2006b)]. All the ALS mice are heterozygous for a $12 \mathrm{~kb}$ genomic DNA fragment encoding the human mutant SOD1 transgene, under its endogenous promoter.

Survival analysis. CypD-null mice $\left(\mathrm{CypD}^{-1-}\right)$ were mated to heterozygous SOD $1^{\mathrm{G} 37 \mathrm{R}}$, SOD $1^{\mathrm{G} 85 \mathrm{R}}$, and SOD $1^{\mathrm{G} 93 \mathrm{~A}}$ ALS mice and the resulting CypD ${ }^{+/-} /$mutant SOD1 mice were mated to $\mathrm{CypD}^{+/-}$mice to obtain the experimental cohorts of CypD ${ }^{-1-} /$ mutant SOD 1 animals that were compared with $\mathrm{CypD}^{+/+} /$mutant SOD1 littermates. Mice were weighed weekly as an objective and unbiased measure of disease course (Lobsiger et al., 2009). Time of disease onset was retrospectively determined as the time when mice reached peak body weight, which is observed before any motor performance decline as measured by grip strength or rotarod (Liu et al., 2005; Schütz et al., 2005; Matsumoto et al., 2006). The time of early disease was defined as the age at which the animals had lost $10 \%$ of their maximal weight (which is accompanied by gait alterations, failure of hindlimb splaying reflex, and loss of grip strength without obvious signs of paralysis). This early disease stage is followed by the appearance of progressive paralysis. During the symptomatic phase, mice were observed daily and end stage was defined by paralysis so severe that the animal could not right itself within $30 \mathrm{~s}$ when placed on its side, an endpoint frequently used for SOD1 mutantexpressing mice and one that was consistent with the requirements of the Animal Care and Use Committee of the University of California.

Grip strength. Grip strength was measured weekly using a Grip Strength Meter (Columbus Instruments) on cohorts $(n \geq 12)$ made up of approximately the same number of males and females. Mice were allowed to grip a triangular bar only with hindlimbs, followed by pulling the mice until they released; five force measurements were recorded in each separate trial.

Immunofluorescence. Mice were perfused intracardially with 4\% paraformaldehyde in $0.1 \mathrm{M}$ Sorenson's phosphate buffer, $\mathrm{pH}$ 7.2. The entire spinal cord was dissected, postfixed for $2 \mathrm{~h}$ in fixative, and transferred in a $30 \%$ sucrose phosphate buffer for at least $2 \mathrm{~d}$. The lumbar spinal cord was embedded in OCT compound (Sakura) and snap frozen in isopentane cooled at $-40^{\circ} \mathrm{C}$ on dry ice. Floating lumbar spinal cord cryosections $(30 \mu \mathrm{m})$ were incubated in a blocking solution containing PBS, $0.5 \%$ Tween 20, 1.5\% bovine serum albumin (BSA) for $1 \mathrm{~h} 30 \mathrm{~min}$ at room temperature and then in PBS, $0.3 \%$ Triton X-100 overnight at room temperature with the following primary antibodies: polyclonal rabbit antibodies against ChAT (1:300; Millipore Bioscience Research Reagents), GFAP (1:1000; Dako), and Ibal (1:500) or monoclonal mouse antibodies against misfolded SOD1: DSE2 3H1 (1:5000; kindly provided by Neil Cashman; Vande Velde et al., 2008), B8H10 (1:1000) and C4F6 (1:500, MediMabs), and D3H5 (1:500, kindly provided by Jean-Pierre Julien; Gros-Louis et al., 2010). Primary antibodies were washed with PBS and then detected using donkey anti-rabbit or anti-mouse FITC or Cy3 (1:500)-coupled secondary antibodies (Jackson ImmunoResearch). The sections were washed with PBS and mounted. Analysis was performed on a Nikon Eclipse laser scanning confocal microscope. Fluorescence intensity from unsaturated images captured with identical confocal settings (minimum of four spinal cord sections were imaged per animal) was quantified using NIS elements software (Nikon).

Motor neuron counting. ChAT-positive ventral horn motor neurons were counted from 25-35 lumbar spinal cord cryosections (per animal) spaced $360 \mu \mathrm{m}$ apart and expressed as the average of total motor neurons counted divided by the number of sections.

\section{Neuromuscular junction denervation}

Gastrocnemius muscle was dissected from perfused mice and prepared as described (see above, Immunofluorescence). Floating 40- $\mu$ m-thick longitudinal sections of gastrocnemius were incubated in a blocking solution containing PBS, $0.5 \%$ Tween 20, $1.5 \%$ BSA for $4 \mathrm{~h}$ at room temperature and then in PBS, $0.3 \%$ Triton X-100 overnight at room temperature with the polyclonal rabbit anti-synaptophysin antibody at 1:50 (Invitrogen). The sections were washed with PBS and then incubated first with donkey anti-rabbit Cy3 (Jackson ImmunoResearch) and $\alpha$-bungarotoxin-Alexa 488 (Invitrogen) at 1:500 for $1 \mathrm{~h}$ at room temperature and then with fluoromyelin red (Invitrogen) at 1:300 for $30 \mathrm{~min}$. The sections were further washed with PBS and mounted. Analysis was performed on a Nikon Eclipse laser scanning confocal microscope. A total of $\sim 1000$ neuromuscular junctions (NMJs) were counted from at least 10 sections of gastrocnemius. Individual NMJs were considered as innervated when synaptophysin staining covered at least $50 \%$ of the area of $\alpha$-bungarotoxin staining.

Morphometric analysis of axons. Mice were perfused intracardially with $4 \%$ paraformaldehyde in $0.1 \mathrm{~m}$ Sorenson's phosphate buffer, $\mathrm{pH} 7.2$, and the $\mathrm{L} 5$ lumbar roots were dissected and conserved in fixative at $4^{\circ} \mathrm{C}$. L5 roots were embedded in Epon-Araldite as described in the electron microscopy section, thick sections $(0.75 \mu \mathrm{m})$ were prepared and stained for light microscopy with toluidine blue. Cross sections of L5 motor axons were analyzed at each age group. Axonal diameters were measured using the Bioquant Software and the number of large caliber axons with diameters $>3.5 \mu \mathrm{m}$ ( $\alpha$ motor axons) was determined.

Electron microscopy. Mice were perfused intracardially with $0.1 \mathrm{M} \mathrm{ca}-$ codylate buffer, $\mathrm{pH} 7.2-7.4$, containing $200 \mathrm{~mm}$ sucrose at room temperature for $5 \mathrm{~min}$ followed by fixative solution containing $4 \%$ formaldehyde, and $2.5 \%$ glutaraldehyde in $0.1 \mathrm{M}$ cacodylate buffer, $\mathrm{pH}$ $7.2-7.4$, supplemented with $200 \mathrm{~mm}$ sucrose at $4^{\circ} \mathrm{C}$. Following perfusion, the spinal cord and the lumbar L5 motor root were dissected and placed in fixative until embedding. A $2 \mathrm{~mm}$ thick section was obtained from the lumbar spinal cord. The tissue was rinsed in $0.1 \mathrm{~m}$ sodium cacodylate buffer, osmicated with $2 \%$ osmium tetroxide in cacodylate buffer, dehydrated through ascending ethyl alcohol concentrations, rinsed with acetone and incubated overnight in 1:1 acetone/Epon-Araldite (Araldite 502 Resin, dodecenyl succinic anhydride, Eponate 12 resin, components purchased from Ernest F. Fullam). The sections of spinal cord and the motor roots were rotated for $2 \mathrm{~h}$ in $2: 1$ acetone/Epon-Araldite, $2 \mathrm{~h}$ in pure Epon-Araldite and transferred to silicon molds to harden $65^{\circ} \mathrm{C}$ for $48 \mathrm{~h}$. Ultrathin cross-sections $(70 \mathrm{~nm}$ ) were cut from the ventral horn of the spinal cord and the L5 motor root and stained with $1 \%$ uranyl acetate, prepared in $50 \%$ ethanol, for $10 \mathrm{~min}$, and then with Reynold's lead citrate for $5 \mathrm{~min}$. In ventral horn ultrathin sections, the soma of motor neurons were identified by size and nuclear morphology. Images were taken of the somal mitochondria (5-20 mitochondria per motor neuron soma) from all the motor neurons present in the section (5-10 motor neurons were found per section of ventral horn). In L5 motor roots, larger caliber axons lacking obvious features of degeneration, when observed at low magnification, were selected and high-power images were taken of all the mitochondria within each axon (1-10 mitochondria were found per axon). The area of all the somal and axonal mitochondria in each image was 

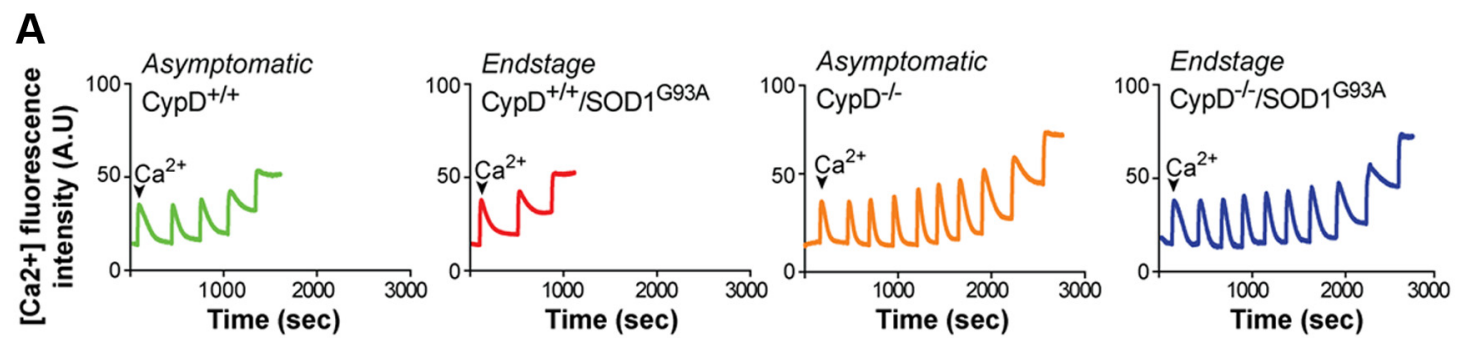

\section{B}
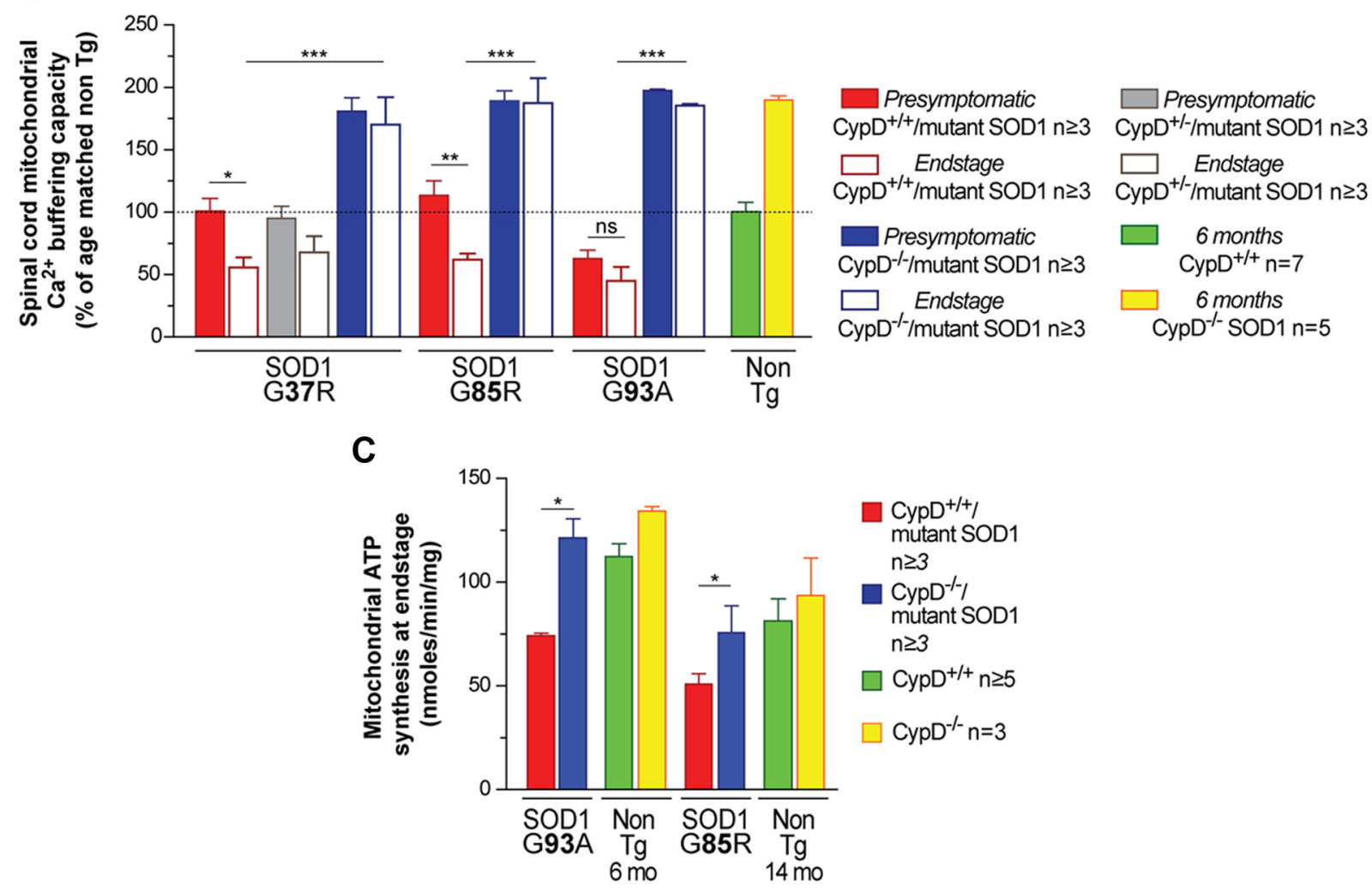

Figure 1. Deleting cyclophilin D improves mitochondrial calcium buffering capacity and mitochondrial ATP synthesis throughout disease in mutant SOD1-expressing mice. A, Representative traces of mitochondrial $\mathrm{Ca}^{2+}$ uptake capacity from spinal cords of asymptomatic nontransgenic animals (CypD ${ }^{+/+}$; green) $\left(\mathrm{CypD}^{-/-}\right.$; orange) and from end stage CypD ${ }^{+/+} / \mathrm{SODD}^{\mathrm{G}}{ }^{\mathrm{G} 3 \mathrm{~A}}(\mathrm{red}$ ) and $\mathrm{CypD}^{-1-} / \mathrm{SOD}^{693 \mathrm{~A}}$ (blue) animals. The peaks correspond to sequential bolus additions of $30 \mathrm{nmol}$ of $\mathrm{Ca}^{2+}$. The downward deflections reflect mitochondrial $\mathrm{Ca}^{2+}$ uptake. $\boldsymbol{B}$, Relative $\mathrm{Ca}^{2+}$ capacity of mitochondria isolated from spinal cords of CypD $D^{+/+} /$mutant SOD1 and CypD ${ }^{-1-}$ /mutant SOD1 animals at the presymptomatic stage and end stage of disease. The bar graph represents mean \pm SEM. ${ }^{*} p<0.05,{ }^{* *} p<0.01,{ }^{* * *} p<0.001 ; n s: p>0.05$. The dotted line at $100 \%$ corresponds to $\mathrm{Ca}^{2+}$ capacity of mitochondria isolated from spinal cords of age-matched nontransgenic

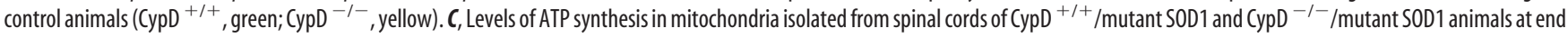
stage disease and from age-matched nontransgenic controls at 6 and 14 months of age. The bar graph represents mean \pm SEM. ${ }^{*} p<0.05$.

determined using ImageJ software. 50 to 170 spinal cord motor neuron mitochondria were analyzed per animal and two animals were analyzed per condition. 150 to 300 L5 motor axon mitochondria were analyzed per animal and three animals were analyzed per condition.

Mitochondrial isolation and purification. The spinal cord was dissected from disease-matched $\mathrm{CypD}^{-/-} /$mutant SOD1 and CypD ${ }^{+/+} /$mutant SOD1 mice and mitochondria were isolated and purified as previously described (Vande Velde et al., 2008). Spinal cords were homogenized on ice in five volumes of ice-cold homogenization buffer (HB) composed of $210 \mathrm{~mm}$ mannitol, $70 \mathrm{~mm}$ sucrose, $1 \mathrm{~mm}$ EDTA-(Tris), and $10 \mathrm{~mm}$ Tris$\mathrm{HCl}, \mathrm{pH} 7.2$, supplemented with protease inhibitors (Roche) and $0.45 \%$ of free fatty acid BSA. Homogenates were centrifuged at $1000 \times g$ for 5 $\min$. Supernatants were recovered and centrifuged again at $1000 \times g$ for $5 \mathrm{~min}$. Supernatants were centrifuged at $12,000 \times g$ for $10 \mathrm{~min}$ to yield crude mitochondrial pellets (heavy membrane fraction). Mitochondriaenriched pellets were gently resuspended in $\mathrm{HB}$ and then adjusted to $12 \%$ Optiprep (iodixanol) and centrifuged at 17,000 $\times g$ for $10 \mathrm{~min}(\mathrm{SW}-55$; Beckman). The majority of the myelin (at the top of the sample) was removed and the mitochondria were washed once with $\mathrm{HB}$ (without BSA and EDTA) to remove the Optiprep. The mitochondria-enriched pellets were gently resuspended in a minimal amount of $\mathrm{HB}$ buffer and protein concentration was measured by Bradford assay. Mitochondria from nontransgenic animals isolated with this method have a respiratory capacity that is in the expected range (average $270 \mathrm{pmol} / \mathrm{min} / \mu \mathrm{g}$ protein using glutamate/malate/pyruvate as respiratory substrates) and are tightly coupled (respiratory control ratio average of 8.9).

Measurement of mitochondrial calcium buffering capacity. Mitochondrial $\mathrm{Ca}^{2+}$ capacity was estimated with the $\mathrm{Ca}^{2+}$-sensitive Calcium Green $5 \mathrm{~N}$ fluorescent dye (Invitrogen). Incubation medium was composed of $125 \mathrm{~mm} \mathrm{KCl}, 20 \mathrm{~mm}$ HEPES, pH 7.2, $2 \mathrm{~mm} \mathrm{KH}_{2} \mathrm{PO}_{4}, 2 \mathrm{~mm}$ $\mathrm{MgCl}_{2}, 5 \mathrm{~mm}$ succinate, $1 \mu \mathrm{M}$ rotenone, and $0.2 \mathrm{~mm} \mathrm{ADP}$, with $1 \mu \mathrm{g} / \mathrm{ml}$ oligomycin and $1 \mu \mathrm{M}$ Calcium Green $5 \mathrm{~N}$. Calcium Green $5 \mathrm{~N}$ does not enter into mitochondria, and its fluorescence reflects the extramitochondrial $\mathrm{Ca}^{2+}$ concentration. Bolus additions of $\mathrm{CaCl}_{2}$ were made to the 60 $\mu \mathrm{g}$ of mitochondria in suspension in $30 \mathrm{nmol}$ increments and changes in Calcium Green $5 \mathrm{~N}$ fluorescence were recorded at an emission of $532 \mathrm{~nm}$ with a QuantaMaster spectrofluorometer (Photon Technology International, Inc). 

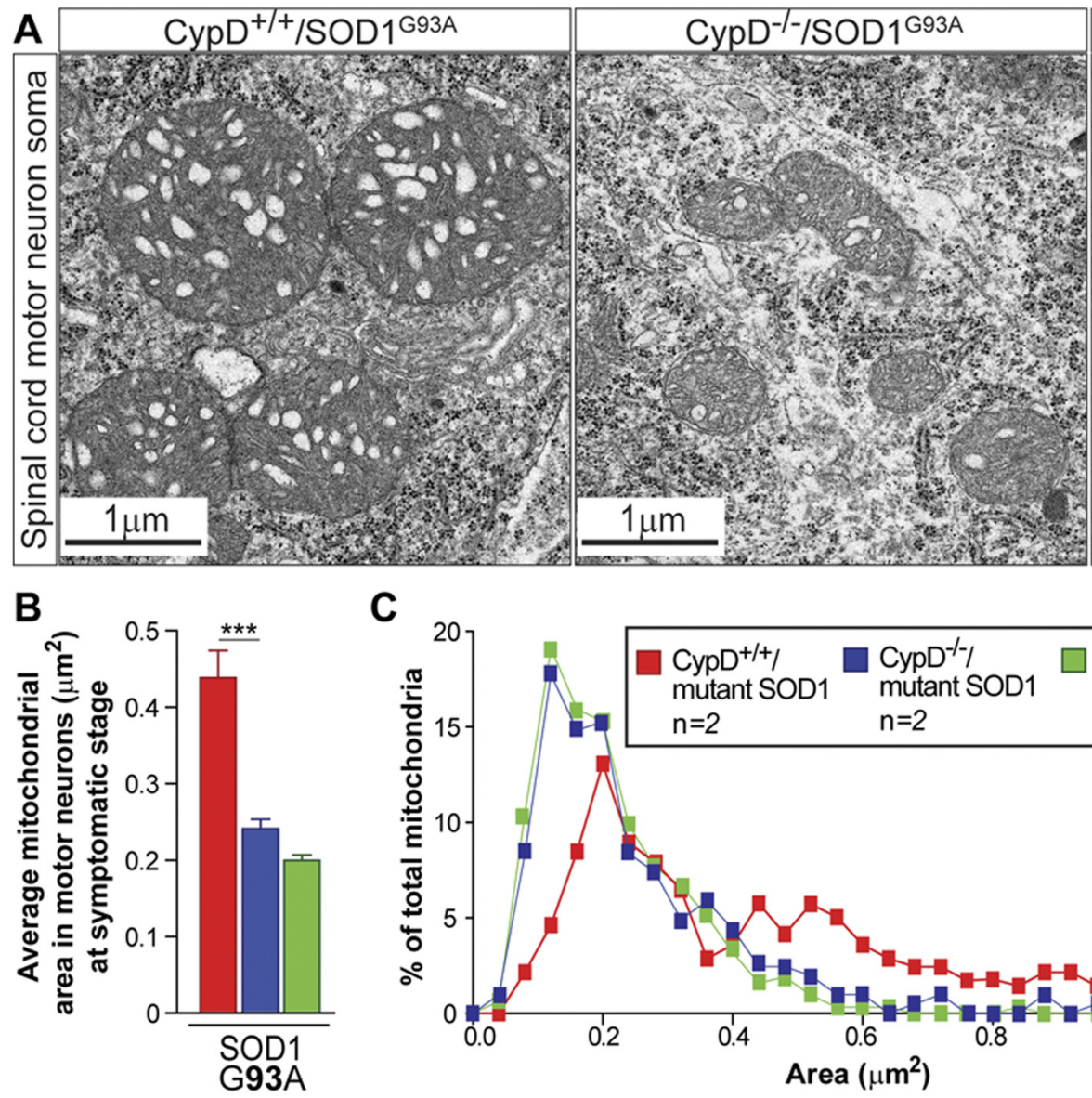

C

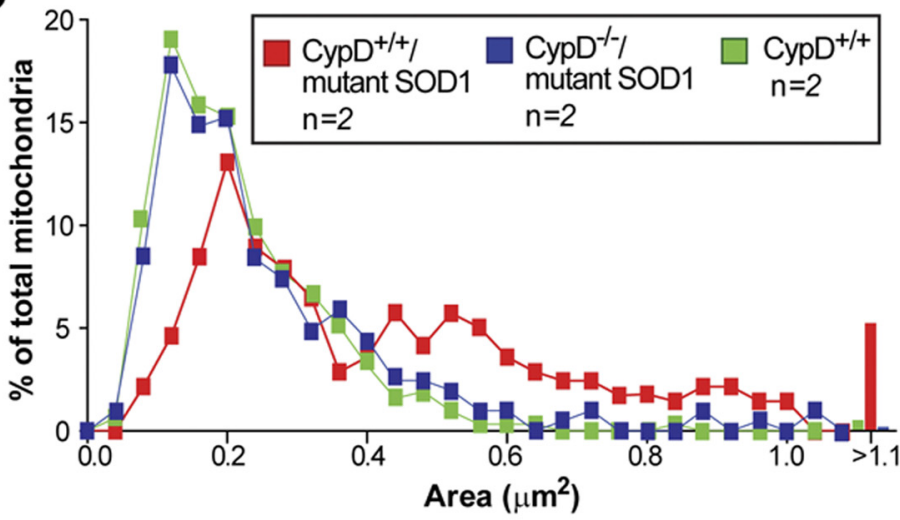

Non transgenic
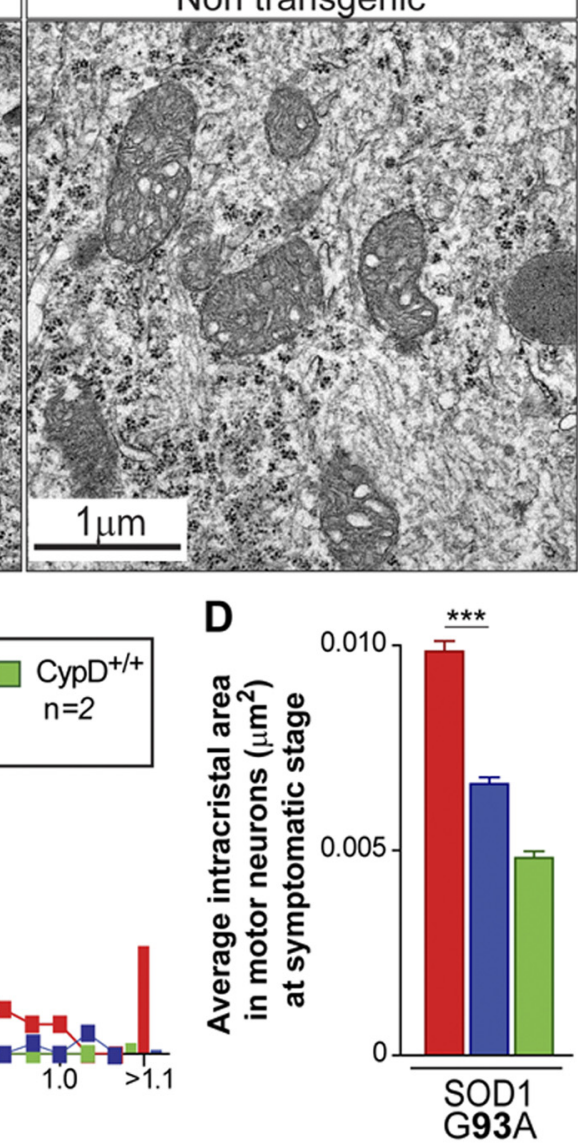

Figure 2. Deleting cyclophilin D reduces mitochondrial damage in spinal cord motor neurons throughout disease in mutant SOD1-expressing mice. $\boldsymbol{A}$, Electron micrographs of motor neuron mitochondria from cross-sections of spinal cords from CypD ${ }^{+/+} / \mathrm{SOD} 1^{\mathrm{G} 93 \mathrm{~A}}$ and CypD ${ }^{-/-} / \mathrm{SOD} 1^{\mathrm{G} 93 \mathrm{~A}}$ animals at a symptomatic stage of disease and from nontransgenic age-matched controls. Scale bar, $1 \mu \mathrm{m}$. B, Average area of mitochondria in spinal cord motor neurons of CypD ${ }^{+/+} / \mathrm{SOD} 1^{\mathrm{G} 93 \mathrm{~A}}$ and CypD $^{-/-} / \mathrm{SOD}^{\mathrm{G} 93 \mathrm{~A}}$ animals at a symptomatic stage of disease and in nontransgenic age-matched controls. The bar graph represents mean \pm SEM. ${ }^{* * *} p<0.001$. C, Distribution of mitochondrial area as a percentage of total mitochondrial population analyzed in $\boldsymbol{B}$. The percentage of mitochondria with area $>1.1 \mu \mathrm{m}^{2}$ for each genotype is represented in the bar graph. $D$, Average area of mitochondrial intracristae space in spinal cord motor neurons of CypD ${ }^{+/+} / \mathrm{SOD} 1^{\mathrm{G} 93 \mathrm{~A}}$ and $\mathrm{CypD}^{-1-} / \mathrm{SOD} 1^{\mathrm{G}}{ }^{\mathrm{GA}}$ animals at a symptomatic stage of disease and in nontransgenic age-matched controls. The bar graph represents mean \pm SEM. ${ }^{* * *} p<0.001$.

Measurement of ATP synthesis. Spinal cord mitochondrial proteins were used to measure ATP synthesis with a luciferase/luciferin-based system as described previously (Johnston et al., 2000). Spinal cord mitochondria-enriched pellets $(30 \mu \mathrm{g})$ were resuspended in $100 \mu \mathrm{l}$ of buffer A ( $150 \mathrm{~mm} \mathrm{KCl,} 25 \mathrm{~mm}$ Tris-HCl, $2 \mathrm{~mm}$ potassium phosphate, 0.1 mM $\mathrm{MgCl}_{2}$, pH 7.4) with $0.1 \% \mathrm{BSA}, 1 \mathrm{~mm}$ malate, $1 \mathrm{~mm}$ glutamate, and buffer B (containing $0.8 \mathrm{~mm}$ luciferin and $20 \mathrm{mg} / \mathrm{ml}$ luciferase in $0.5 \mathrm{M}$ Tris-acetate, $\mathrm{pH}$ 7.75). The reaction was initiated by addition of $0.1 \mathrm{~mm}$ ADP and monitored for 5 min using a microplate reader (Tecan). Luminescence of an ATP standard curve (containing 0, 0.05, 0.1, 0.25, 0.5, and $1.0 \mathrm{~mm}$ ATP solution in buffer A and buffer B) was also measured in parallel to determine the ATP synthesis rate (in $\mathrm{nmol} / \mathrm{min} / \mathrm{mg}$ mitochondrial protein).

Immunoprecipitation and immunoblotting. Spinal cords from $\mathrm{CypD}^{-/-}$or CypD ${ }^{+/+}$mutant SOD1 mice (either 12 or 13-14 months of age) were homogenized in $\mathrm{HB}$ buffer plus protease inhibitors. The lysates were centrifuged for $10 \mathrm{~min}$ at $1000 \times g$ and either the resulting supernatants (clarified tissue extract) or the heavy membrane fractions resuspended in HB buffer as described above were supplemented with $150 \mathrm{~mm} \mathrm{KCl}$ and $0.5 \% \mathrm{NP}-40$ and further incubated overnight at $4^{\circ} \mathrm{C}$ with misfolded SOD1 B8H10 antibody (MediMabs) previously crosslinked to Dynabeads protein G (Invitrogen) with dimethyl pimelimidate (Pierce) according to the manufacturer's instructions. The beads were magnetically isolated and washed three times with immunoprecipitation (IP) buffer. Samples were eluted with boiling in $2.0 \times$ sample buffer without dithiothreitol. Immunoprecipitated proteins were separated by SDS-PAGE, transferred to nitrocellulose membranes, and probed with the indicated antibodies followed by horseradish peroxidase-conjugated secondary antibodies (Jackson Immunochemicals). Pico ECL (Pierce) was used to detect immunoreactive bands. Primary antibodies against SOD1 (C-17; Santa Cruz Biotechnology), GAPDH (Abcam), prohibitin (Neomarkers), and cyclophilin D (Mitosciences) were used for immunoblotting.

\section{Size exclusion chromatography}

One mouse spinal cord was homogenized in $\mathrm{HB}$ buffer (10 mm Tri-HCl, pH 7.4, 150 mм KCl, 1 mм EDTA, 100 mм iodoacetamide, 0.5\% NP-40) and spun at $5000 \mathrm{~g}$ for $5 \mathrm{~min}$ at $4^{\circ} \mathrm{C}$. The supernatant $(1 \mathrm{mg})$ was loaded on a Superose 6 column (GE Healthcare) equilibrated in $10 \mathrm{~mm}$ Tri-HCl, $\mathrm{pH} 7.4,150 \mathrm{~mm} \mathrm{KCl}, 1 \mathrm{~mm}$ EDTA, $0.5 \% \mathrm{NP}-40$ at a flow rate of 0.25 $\mathrm{ml} / \mathrm{min}$ at $4^{\circ} \mathrm{C}$. Fractions of $1 \mathrm{ml}$ were collected. Then 75 and $40 \mu \mathrm{l}$ of the collected fractions $4-11$ and 13-19, respectively, were further analyzed by Slot blotting using a goat anti-SOD1 antibody (C-17; Santa Cruz Biotechnology). The calibration of the size exclusion column was performed with molecular weight markers ranging from $29 \mathrm{kDa}$ to $2 \mathrm{MDa}$.

\section{Results}

Deleting cyclophilin D improves mitochondrial $\mathrm{Ca}^{2+}$ buffering capacity, ATP synthesis, and attenuates mitochondrial damage in mutant SOD1 mice

To determine whether increasing mitochondrial $\mathrm{Ca}^{2+}$ capacity alters SOD1 mutant-mediated ALS disease course and pathogenesis, we bred transgenic mice expressing mutant SOD1 mice that 

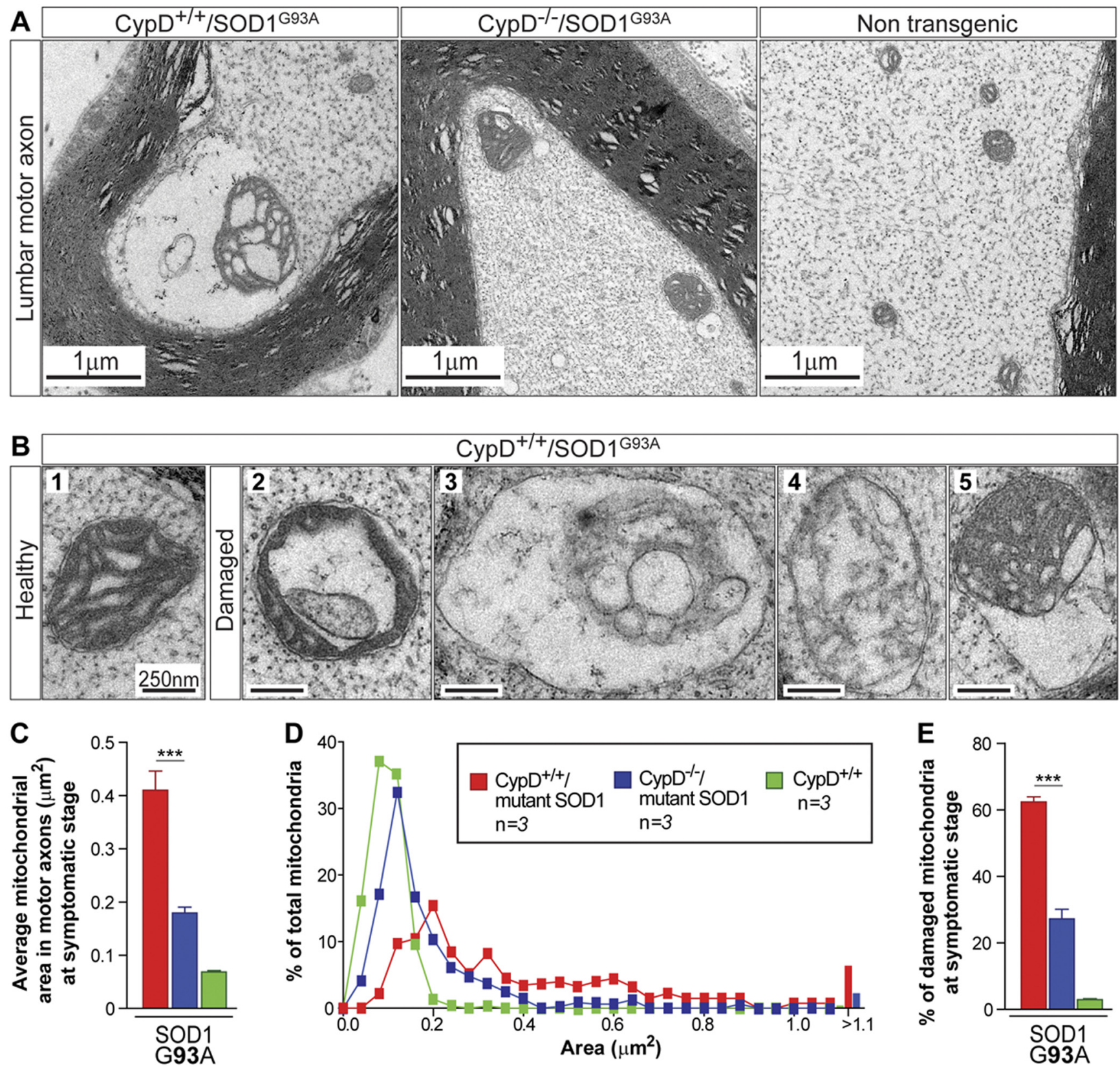

Figure 3. Deleting cyclophilin $D$ reduces mitochondrial damage and degeneration in lumbar motor axons throughout disease in mutant SOD1-expressing mice. $A$, Electron micrographs of mitochondria from cross sections of lumbar $\mathrm{L} 5$ motor axon from CypD ${ }^{+/+} / S 0 D 1^{693 A}$ and $C y D^{-/-} / S O D 1^{693 A}$ animals at a symptomatic stage of disease and from nontransgenic age-matched controls. Scale bar, $1 \mu \mathrm{m}$. B, Electron micrographs of mitochondria from cross sections of lumbar $\mathrm{L} 5$ motor axon from CypD ${ }^{+/+} / S 0 D 1^{G 93 A}$ animals at a symptomatic stage of disease. Scale bar, 250 $\mathrm{nm} .1$ illustrates an example of a healthy mitochondrion and 2-5 illustrate representative examples of damaged mitochondria: mitochondria with disorganized cristae (2), degenerating within vacuoles (3), with diluted (low electron density) matrix, (4) or abnormal distention between the inner and outer membranes with rupture of the outer membrane (5). $C$, Average area of mitochondria in lumbar motor axons of $\mathrm{CypD}{ }^{+/+} / \mathrm{SOD} 1^{\mathrm{G} 93 \mathrm{~A}}$ and $\mathrm{CypD}^{-/-} / \mathrm{SOD} 1^{\mathrm{G} 93 \mathrm{~A}}$ animals at a symptomatic stage of disease and in nontransgenic age-matched controls. The bar graph represents mean \pm SEM. ${ }^{* * *} p<0.001$. D, Distribution of mitochondrial area as a percentage of the total mitochondrial population analyzed in $\boldsymbol{C}$. The percentage of mitochondria with area $>1.1 \mu \mathrm{m}^{2}$ for each genotype is represented in the bar graph. $\boldsymbol{E}$, Percentage of damaged mitochondria with the type of damage illustrated in $\boldsymbol{B}(2-5)$ in lumbar motor axons of $\mathrm{CypD}^{+/+} / \mathrm{SODD}^{693 \mathrm{~A}}$ and $\mathrm{CypD}{ }^{-/-} /$ SOD1 ${ }^{693 \mathrm{~A}}$ animals at a symptomatic stage of disease and in nontransgenic age-matched controls. The bar graph represents mean \pm SEM. ${ }^{* * *} p<0.001$.

develop adult-onset fatal paralysis with Ppif ${ }^{-/-}$mice, which completely lack CypD expression (Basso et al., 2005). To ensure that conclusions drawn from deleting CypD would be broadly applicable to mutant SOD1-mediated ALS, all three most prominently used ALS mouse models were chosen so as to test mutants of markedly different biochemical characteristics, including fully dismutase active (SOD $1^{\mathrm{G} 37 \mathrm{R}}$ ) (Boillée et al., 2006b), partially active SOD1 ${ }^{\text {G93A }}$ (Gurney et al., 1994), and inactive (SOD1 ${ }^{\mathrm{G} 85 \mathrm{R}}$ ) mutant SOD1 (Bruijn et al., 1997). Additionally, the SOD1 ${ }^{\text {G85R }}$ - and SOD $1{ }^{\mathrm{G} 37 \mathrm{R}}$-expressing mouse lines used develop more slowly progressing disease from mutant SOD1 accumulation at levels equal to or modestly above, respectively, those of the endogenous mouse protein, thus mimicking more closely the levels of mutant SOD1 accumulation in ALS patients. Finally, SOD $1{ }^{\mathrm{G} 93 \mathrm{~A}}$ expressing mice are the most widely used ALS models and develop very rapidly progressing disease from high level accumulation of mutant SOD1 (to levels 5- to 15-fold above endogenous SOD1). 

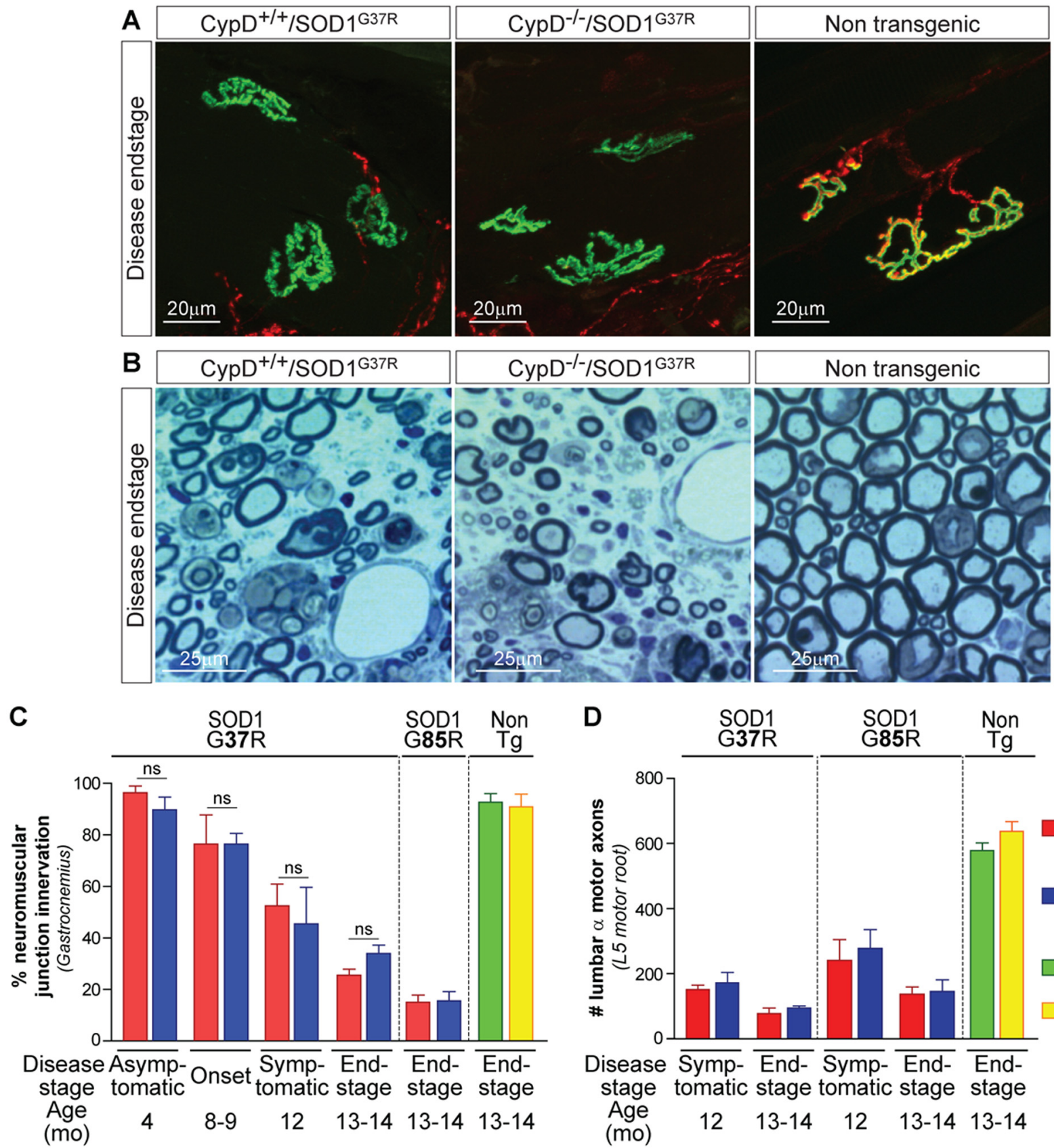

Figure 4. Improving mitochondrial function by deleting CypD in mutant SOD1 animals does not prevent muscle denervation and axonal degeneration. $\boldsymbol{A}$, Representative micrographs of gastrocnemius muscle from CypD ${ }^{+/+} / S O D 1^{G 37 R}$ and $\mathrm{CypD}^{-/-} / \mathrm{SOD}^{\mathrm{G}}{ }^{37 \mathrm{R}}$ animals at end stage disease and from age-matched nontransgenic littermates processed for immunofluorescence to reveal axons (red) using an antibody recognizing synaptophysin and fluoromyelin red and using $\alpha$-bungarotoxin (green) to reveal muscle endplates. Scale bar, $20 \mu \mathrm{m} . \boldsymbol{B}$, Representative micrographs of lumbar motor axons from CypD ${ }^{+/+} / S O D 1^{\text {G37R }}$ and $C y p D^{-1-} / S O D 1^{\text {G37R }}$ animals at end stage disease and from age-matched nontransgenic littermates. Scale bar, $25 \mu \mathrm{m}$. $C$, Quantification of innervation at the NMJ of the gastrocnemius muscle from CypD ${ }^{+/+} /$mutant SOD1 and CypD ${ }^{-1-} /$ mutant SOD1 animals throughout disease stages for mutant SOD ${ }^{\text {G37R }}$ and at end stage for CypD ${ }^{+/+} / S O D 1^{685 R}, \mathrm{CypD}^{-/-} / \mathrm{SOD} 1^{685 R}$, and age-matched nontransgenic littermates. The bar graph represents mean \pm SEM. ns: $p>0.05$. D, Quantification of the total number of $\alpha$-motor axons in the lumbar $\mathrm{L} 5$ motor root from CypD ${ }^{+/+} /$mutant SOD1 and CypD ${ }^{-1-} /$ mutant SOD1 animals at a symptomatic stage and at end stage of disease.

Deleting CypD resulted in a doubling throughout disease of the $\mathrm{Ca}^{2+}$ storage capacity in mitochondria isolated from spinal cords of CypD ${ }^{-1-} / \mathrm{SOD} 1^{\mathrm{G} 37 \mathrm{R}}$ and $\mathrm{CypD}{ }^{-1-} / \mathrm{SOD} 1^{\mathrm{G} 85 \mathrm{R}}$ animals (Fig. $1 A, B$ ). Importantly, the $\sim 50 \%$ reduction in $\mathrm{Ca}^{2+}$ storage capacity observed at disease end stage in $\mathrm{CypD}^{+/+} / \mathrm{SOD} 1^{\mathrm{G} 37 \mathrm{R}}$ and $\mathrm{CypD}^{+/+} / \mathrm{SOD} 1{ }^{\mathrm{G} 85 \mathrm{R}}$ animals, compared with presymptomatic stages or age-matched nontransgenic mice, was completely reversed by deletion of CypD in mutant SOD1 animals compared with presymptomatic stages or age-matched CypD-deleted mice. Of note, in the SOD1 ${ }^{\mathrm{G} 93 \mathrm{~A}}$ mice with normal CypD, the decrease in mitochondrial $\mathrm{Ca}^{2+}$ capacity preceded appearance of motor symptoms [occurring as early as 6 weeks of age (see presymptomatic $\mathrm{CypD}^{+/+} / \mathrm{SOD} 1^{\mathrm{G} 93 \mathrm{~A}}$ animals in Fig. $1 B$ )] and was completely reversed by deleting CypD.

CypD deletion has previously been reported to restore the activity of mitochondrial respiratory complexes and ATP synthesis in the cortices of aged mice overexpressing a mutant human form of amyloid precursor protein (Du et al., 2008). Compared with age-matched CypD knock-out mice, deletion of CypD in mutant SOD1 transgenic mice completely rescued the $\sim 30-50 \%$ 

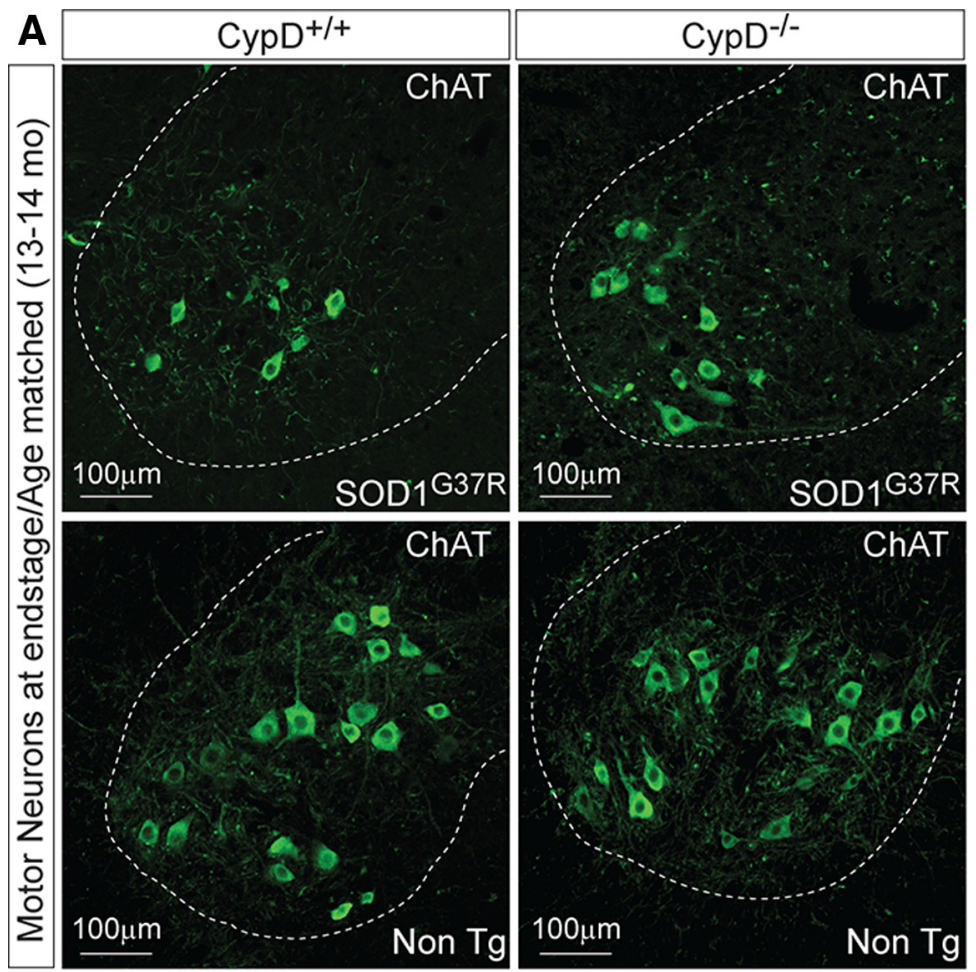

B

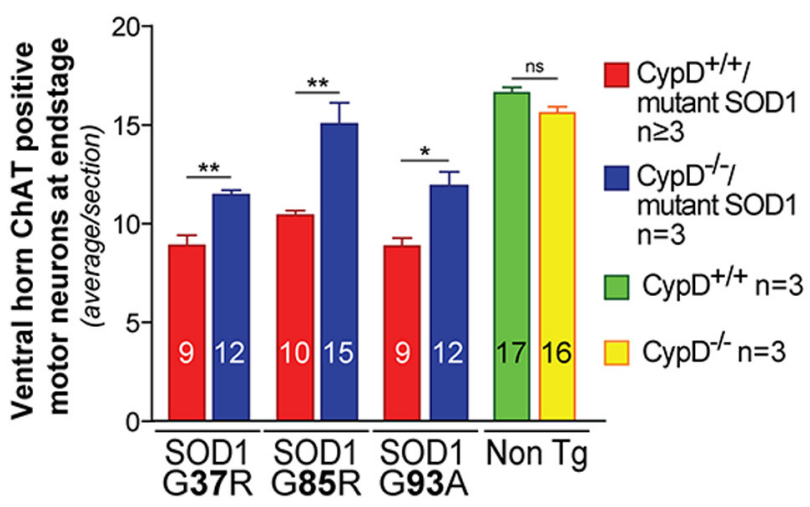

Figure 5. Improving mitochondrial function by deleting CypD in mutant SOD1 animals significantly reduces the loss of motor

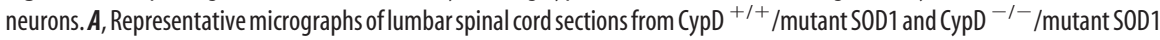
animals at end stage of disease and from age-matched nontransgenic littermates processed for immunofluorescence using an antibody recognizing ChAT to reveal cholinergic motor neurons. Dashed outlines correspond to the boundary between gray and white matter. Scale bar, $100 \mu \mathrm{m}$. B, Quantification of the average number of large cholinergic ventral horn motor neurons per section of lumbar spinal cord from CypD ${ }^{+/+} /$mutant SOD1 and CypD ${ }^{-/-} /$mutant SOD1 animals at end stage disease and in age-matched nontransgenic littermates. The bar graph represents mean \pm SEM. ${ }^{*} p<0.05,{ }^{* *} p>0.01 ;$ ns: $p>0.05$. The number within each bar represents the average number of motor neurons per spinal cord section.

decrease in mitochondrial ATP production observed in isolated spinal cord mitochondria from $\mathrm{CypD}^{+/+} / \mathrm{SOD}^{\mathrm{G} 93 \mathrm{~A}}$ or $\mathrm{CypD}^{+/+} /$ $\mathrm{SOD} 1{ }^{\mathrm{G} 85 \mathrm{R}}$ animals at disease end stage when compared with nontransgenic controls (Fig. 1C).

Mitochondrial swelling resulting in damage to the organelle is a signature of mPTP opening (Bernardi et al., 2006). Electron microscopy was used to determine mitochondrial ultrastructure in spinal cord motor neurons (Fig. 2A), as well as lumbar motor axons (Fig. $3 A$ ) of $\mathrm{CypD}^{+/+} / \mathrm{SOD} 1^{\mathrm{G} 93 \mathrm{~A}}$ and $\mathrm{CypD}^{-/-} /$ SOD ${ }^{\text {G93A }}$ mice. Deleting CypD significantly reduced mitochondrial swelling (measured as the increase in average mitochondrial area and intracristal space) observed in $\mathrm{CypD}^{+/+} / \mathrm{SOD} 1^{\mathrm{G} 93 \mathrm{~A}}$ mice at a symptomatic phase of disease $(100$ d) in both the soma of motor neurons (Fig. $2 A-D)$ and in motor axons (Fig. 3A-E). Mitochondrial swelling was a general feature of the mitochondrial population in motor neurons (Fig. 2C) and their axons (Fig. 3D) as shown by the shift toward larger mitochondrial size in the mitochondrial area distribution of symptomatic CypD ${ }^{+/+} /$ SOD $1^{\text {G93A }}$ mice versus $\mathrm{CypD}^{-/-}$/ SOD1 ${ }^{\text {G93A }}$ mice and age-matched controls. Except for mitochondrial swelling, no other features of mitochondrial abnormalities were observed in the soma of motor neurons of $\mathrm{CypD}^{+/+} / \mathrm{SOD} 1^{\mathrm{G} 93 \mathrm{~A}}$ mice at a symptomatic stage of disease. However, at this time point mitochondrial damage was very clear in the motor axons of CypD ${ }^{+/+} /$ SOD $1^{\text {G93A }}$ mice, with a large number of mitochondria showing distension of the intermembrane space (sometimes containing membranous material), diluted matrix with disorganized cristae, and vacuolization (Fig. $3 A, B$ ). Mitochondrial damage in motor axons was significantly attenuated by deletion of CypD in symptomatic SOD $1^{\mathrm{G} 93 \mathrm{~A}}$ mice (Fig. 3E).

Thus, deleting CypD improved mitochondrial $\mathrm{Ca}^{2+}$ buffering and ATP synthesis capacity in the spinal cord and attenuated mitochondrial swelling within motor neurons and damage of mitochondria in motor axons of ALS mouse models expressing both dismutase active and inactive SOD1 mutants. Furthermore, the simplest interpretation for improved mitochondrial ATP synthesis in the $\mathrm{CypD}^{-1-}$ nervous system is as a consequence of a reduction in $\mathrm{Ca}^{2+}$ dependent mitochondrial damage.

\section{Improved mitochondrial function} significantly reduces loss of motor neurons and glial activation, but does not delay muscle denervation or axonal degeneration

Sustained improvement in mitochondrial function resulting from deletion of CypD in mutant SOD1 animals did not correspond to a delay in the appearance of classical hallmarks of disease. The percentages of denervated NMJs in the gastrocnemius muscles were 73 and $67 \%$ (Fig. $4 A, C$ ), respectively, for $\mathrm{CypD}^{+/+} / \mathrm{SOD} 1^{\mathrm{G} 37 \mathrm{R}}$ and $\mathrm{CypD}^{-1-} / \mathrm{SOD} 1^{\mathrm{G} 37 \mathrm{R}}$ mice. Similarly, 86 and $85 \%$, respectively, of junctions were denervated in $\mathrm{CypD}^{+/+} / \mathrm{SOD} 1^{\mathrm{G} 85 \mathrm{R}}$ and $\mathrm{CypD}^{-/-} / \mathrm{SOD} 1^{\mathrm{G} 8 \mathrm{R}}$ mice. Of note, deleting CypD did not prevent or delay the loss of NMJs at any stage of disease in mutant SOD1 ${ }^{\text {G37R }}$ mice (Fig. $4 C$ ). Similarly, there was no significant difference in the loss of $\alpha$-motor axons throughout disease between $\mathrm{CypD}^{-/-} / \mathrm{SOD} 1^{\mathrm{G} 37 \mathrm{R}}$ or $\mathrm{CypD}^{-/-} / \mathrm{SOD} 1^{\mathrm{G} 85 \mathrm{R}}$ animals, compared with $\mathrm{CypD}{ }^{+/+}$littermates carrying the corresponding mutant SOD1 transgene (Fig. 4B,D; for SOD $1{ }^{\mathrm{G} 37 \mathrm{R}}$, 74 and $73 \%$, lost by a symptomatic stage and $86 \%$ or $85 \%$ lost at disease end stage, 

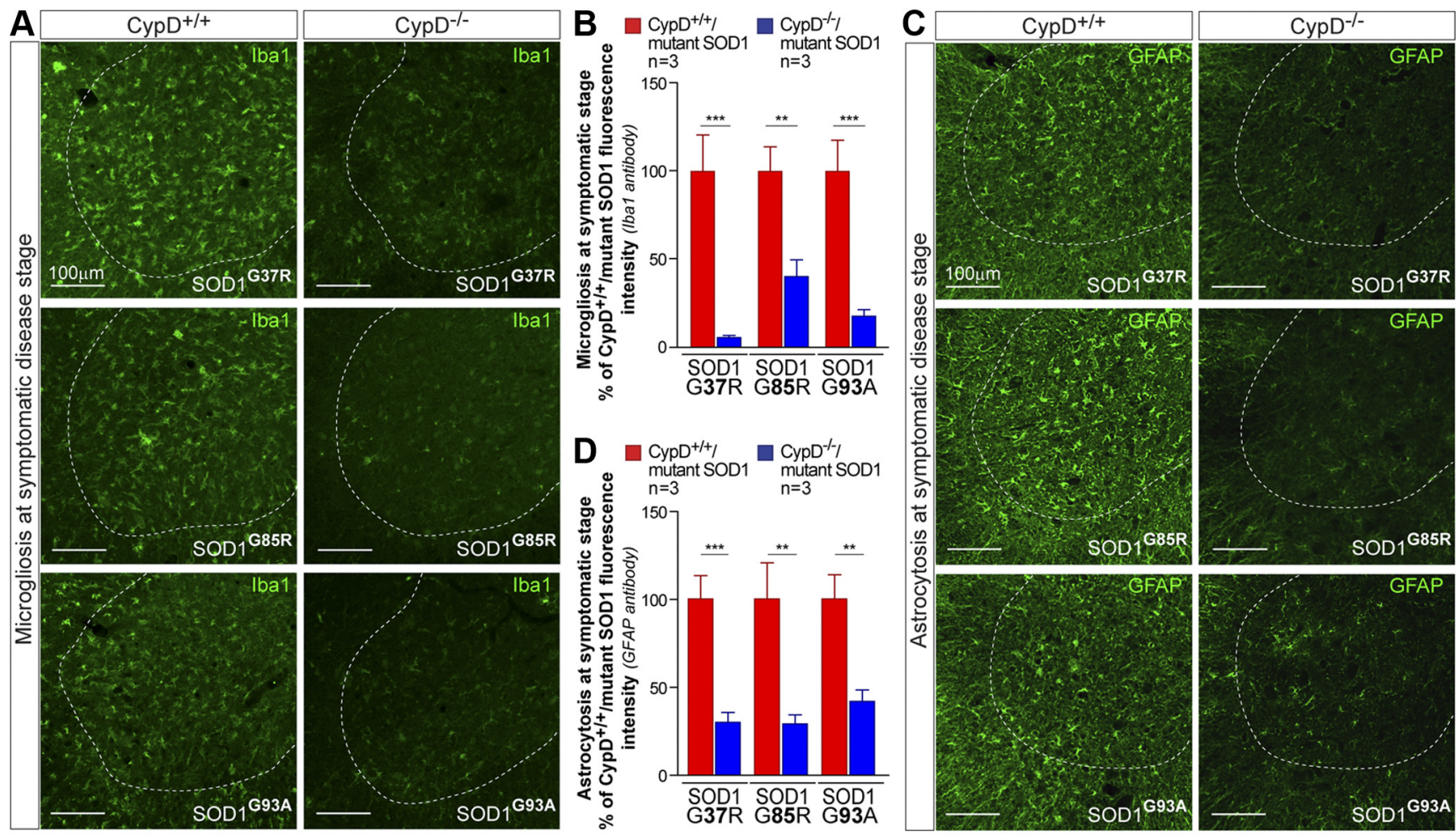

Figure 6. Improving mitochondrial function by deleting CypD in mutant SOD1 animals significantly reduces glial activation. $A$, Representative micrographs of lumbar spinal cord sections from CypD ${ }^{+/+} /$mutant SOD1 and CypD ${ }^{-/-} /$mutant SOD1 animals at a symptomatic stage of disease processed for immunofluorescence using an antibody detecting activated microglia (Ibal). Dashed outlines correspond to the boundary between gray and white matter. Scale bar, $100 \mu \mathrm{m}$. B, Quantification of the relative fluorescence intensity of the Ibal staining of lumbar spinal cord from CypD ${ }^{+/+} /$mutant SOD1 and CypD ${ }^{-/-}$/mutant SOD1 animals at a symptomatic stage of disease. The bar graph represents mean \pm SEM. ${ }^{* *} p<0.01$, ${ }^{* * *} p<0.001$. C, Representative micrographs of lumbar spinal cord sections from CypD ${ }^{+/+} /$mutant SOD1 and CypD ${ }^{-/-} /$mutant SOD1 animals at symptomatic stage of disease processed for immunofluorescence using an antibody-detecting activated astrocytes (GFAP). Dashed outlines correspond to the boundary between gray and white matter. Scale bar, 100 $\mu \mathrm{m} . \mathbf{D}$, Quantification of the relative fluorescence intensity of the GFAP staining of lumbar spinal cord from CypD ${ }^{+/+} / \mathrm{mutant}$ SOD1 and CypD ${ }^{-/-} / \mathrm{mutant}$ SOD1 animals at a symptomatic stage of disease. The bar graph represents mean \pm SEM. ${ }^{* *} p<0.01,{ }^{* * *} p<0.001$.

while for SOD1 ${ }^{\mathrm{G} 85 \mathrm{R}}$ mice, $58 \%$ or $56 \%$, lost at a symptomatic stage and $76 \%$ or $77 \%$ lost by disease end stage).

In contrast, the loss of $\alpha$-motor neurons in the spinal cords of all three mutant SOD1 mice at disease end stage was significantly reduced by deletion of CypD (Fig. $5 A, B$ ) (e.g., with $48 \%$ vs $27 \%$, respectively, of the $\alpha$-motor neurons lost at disease end stage in $\mathrm{CypD}^{+/+} / \mathrm{SOD} 1^{\mathrm{G} 37 \mathrm{R}}$ and $\mathrm{CypD}^{-/-} / \mathrm{SOD} 1^{\mathrm{G} 37 \mathrm{R}}$ mice; $48 \%$ vs $24 \%$, respectively, of $\alpha$-motor neurons lost at disease end stage in $\mathrm{CypD}^{+/+} / \mathrm{SOD} 1^{\mathrm{G} 93 \mathrm{~A}}$ and $\mathrm{CypD}{ }^{-1-} / \mathrm{SOD} 1^{\mathrm{G} 93 \mathrm{~A}}$ mice). Indeed, $\alpha$-motor neuron loss was almost completely suppressed when CypD was deleted in mutant SOD $1{ }^{\mathrm{G} 85 \mathrm{R}}$-expressing mice (Fig. $5 B$ ) (with $39 \%$ vs $4 \%$, respectively, of $\alpha$-motor neurons lost by disease end stage).

Additionally, improved mitochondrial function significantly reduced induction of microglial (Fig. 6A,B) and astroglial (Fig. $6 C, D$ ) activation (scored with Ibal and GFAP immunoreactivity, respectively) in the spinal cord ventral horns of $\mathrm{CypD}^{-1-}$ / SOD $1^{\mathrm{G} 37 \mathrm{R}}$, SOD $1^{\mathrm{G} 85 \mathrm{R}}$, and SOD $1^{\mathrm{G} 93 \mathrm{~A}}$ mice at a symptomatic stage of disease (Fig. $6 B, D$; with reduction in Ibal immunoreactivity of 95,60 , and $87 \%$, respectively, in SOD $1^{\mathrm{G} 37 \mathrm{R}}$, SOD $1{ }^{\mathrm{G} 85 \mathrm{R}}$, and SOD $1{ }^{\text {G93A }}$ CypD-deleted mice and reduction in GFAP immunoreactivity of 71,72 , and $59 \%$, respectively, in SOD $1^{\mathrm{G} 37 \mathrm{R}}$, SOD $1^{\mathrm{G} 85 \mathrm{R}}$ and SOD $1{ }^{\mathrm{G} 93 \mathrm{~A}}$ CypD-deleted mice).

Overall, deletion of CypD improved mitochondrial function in mice expressing SOD1 mutants of different biochemical properties and significantly reduced glial activation and the loss of spinal cord motor neurons, but did not alter motor axon degeneration and neuromuscular denervation.

\section{Improved mitochondrial function reduces accumulation of} misfolded SOD1 aggregates

SOD1-mediated toxicity to motor neurons has long been proposed to be linked to protein aggregates of SOD1 (Deng et al., 1993; Bruijn et al., 1998) that contain misfolded SOD1 as determined using antibodies that recognize epitopes unavailable in the natively folded protein and that bind preferentially or exclusively to misfolded conformers (Rakhit et al., 2007; Gros-Louis et al., 2010; Grad et al., 2011). To determine whether improving mitochondrial function attenuates SOD1-mediated toxicity to motor neurons by reducing the accumulation of misfolded SOD1, we used the monoclonal antibody $\mathrm{B} 8 \mathrm{H} 10$, which recognizes epitopes within exon 3 that are exposed only upon misfolding or denaturation of SOD1 (Gros-Louis et al., 2010; Pickles and Vande Velde, 2012) to detect misfolded SOD1 forms by immunofluorescence on spinal cord sections.

Deleting CypD in all three models of mutant SOD1-mediated disease significantly reduced (by $>80 \%$ ) the accumulation of misfolded SOD1 detected by the B8H10 antibody at a symptomatic stage of disease (Fig. $7 A, B$ ) (with 84,84 , and $83 \%$, respectively, of reduction in misfolded SOD1 accumulation in CypD-deleted SOD $1^{\mathrm{G} 37 \mathrm{R}}, \mathrm{SOD} 1^{\mathrm{G} 85 \mathrm{R}}$, and SOD $1^{\mathrm{G} 93 \mathrm{~A}}$ mice). Similarly, a significant reduction in the accumulation of misfolded SOD1 was observed in $\mathrm{CypD}^{-1-} / \mathrm{SOD} 1^{\mathrm{G} 37 \mathrm{R}}$ at a symptomatic stage of disease when we used different monoclonal antibodies (A5C3 and D3H5), which recognize epitopes within exon 4 or 2, respectively, that are exposed upon misfolding of SOD1 (Gros-Louis et al., 2010; Pickles and Vande Velde, 2012) (Fig. 7C). 

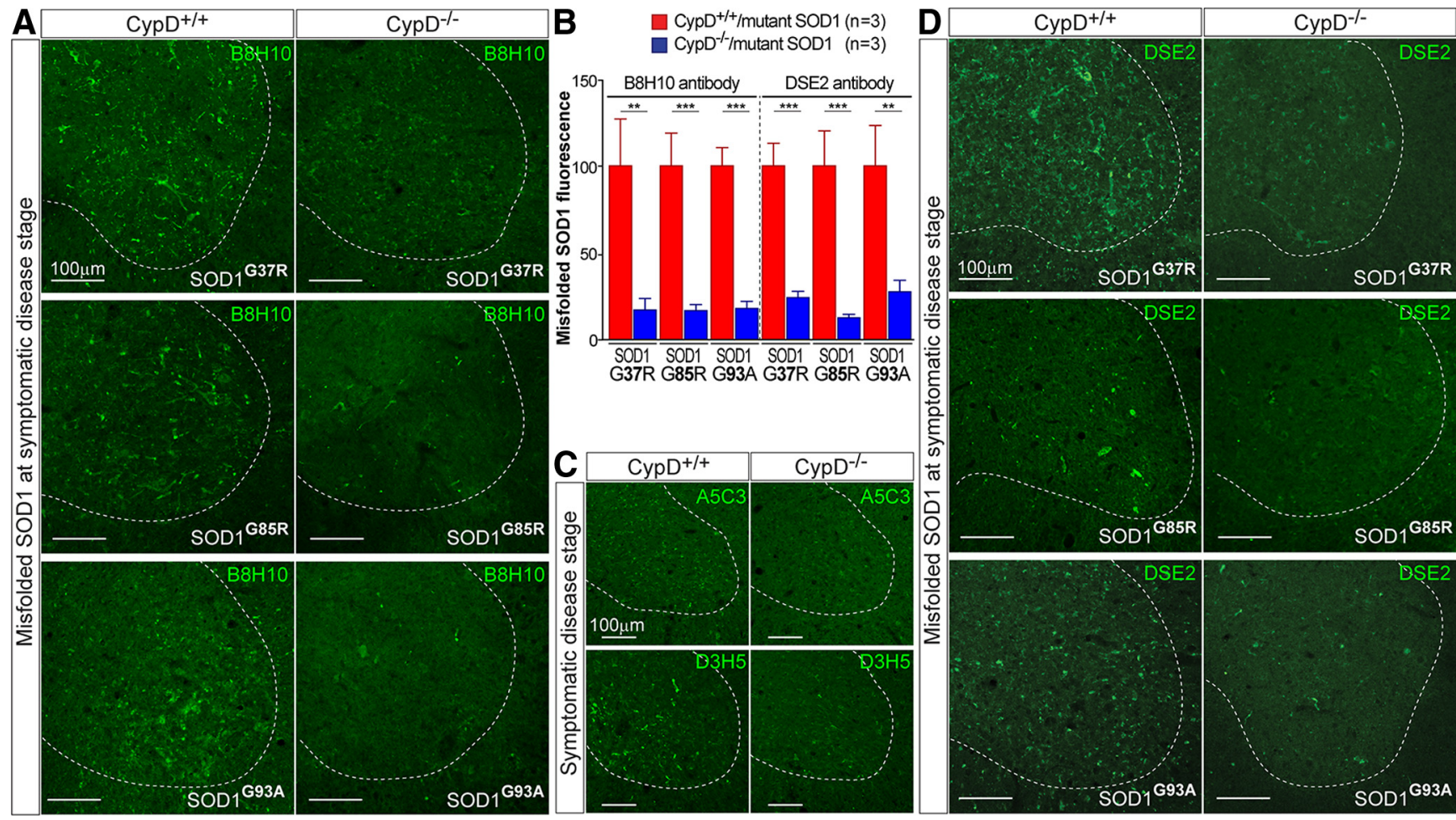

Figure 7. Improving mitochondrial function by deleting CypD in mutant SOD1 animals reduces the accumulation of misfolded forms of mutant SOD1 in the spinal cord at a symptomatic stage of disease. $A_{t}$ $C, D$, Representative micrographs of lumbar spinal cord sections from CypD ${ }^{+/+} /$mutant SOD1 and CypD ${ }^{-/-}$/mutant SOD1 animals at a symptomatic stage of disease processed for immunofluorescence using an antibody-detecting misfolded SOD1: B8H10 (A), A5C3 and D3H5 (C), DSE2 (D). Dashed outlines correspond to the boundary between gray and white matter. Scale bar, $100 \mu \mathrm{m} . \boldsymbol{B}$, Quantification of the relative fluorescence intensity of the B8H10 (A) and DSE2 (D) stainings of lumbar spinal cord from CypD ${ }^{+/+} /$mutant SOD1 and CypD ${ }^{-/-}$/mutant SOD1 animals at a symptomatic stage of disease. The bar graph represents mean \pm SEM. ${ }^{* *} p<0.01,{ }^{* *} p<0.001$.

To examine whether CypD deletion also reduced the accumulation of misfolded SOD1 exposing other disease-specific epitopes, we used a monoclonal antibody (DSE2) developed against the electrostatic loop of SOD1 (amino acids 125-142), a structural element accessible to antibody binding only upon misfolding or denaturation of SOD1 (Grad et al., 2011). Like that seen for the $\mathrm{B} 8 \mathrm{H} 10, \mathrm{~A} 5 \mathrm{C} 3$, and $\mathrm{D} 3 \mathrm{H} 5$ antibodies, the accumulation of misfolded SOD1 detected using the DSE2 antibody was also markedly reduced (by $>70 \%$ ) in CypD-deleted mutant SOD1 mice at a symptomatic stage of disease (Fig. $7 B, D$ ) (with 76,88 , and $73 \%$, respectively, reductions in CypD-deleted SOD $1^{\mathrm{G} 37 \mathrm{R}}, \mathrm{SOD} 1^{\mathrm{G} 85 \mathrm{R}}$, and SOD $1^{\mathrm{G} 93 \mathrm{~A}}$ mice).

To further confirm biochemically that CypD deletion reduces the accumulation of misfolded SOD1, we used immunoprecipitation to measure the levels of non-natively folded SOD1 conformers in detergent lysates of whole spinal cord (Fig. 8A). Significantly less misfolded SOD1 was detected in spinal cords from disease-matched symptomatic CypD ${ }^{-1-}$, SOD $1^{\text {G37R }}$ animals despite similar total levels of SOD1 accumulation (Fig. 8B). Moreover, because a proportion of misfolded SOD1 in the spinal cord of mice expressing SOD1 mutants of different biochemical characteristics is deposited on the surface of, or imported into, mitochondria (Mattiazzi et al., 2002; Liu et al., 2004; Vande Velde et al., 2008), spinal cord fractions enriched in mitochondria were examined for misfolded SOD1 (Fig. $8 \mathrm{~A}$ ). This accumulation, too, was very significantly reduced in SOD $1^{\text {G37R }}$ (Fig. $8 C$ ) and SOD $1^{\text {G85R }}$ (Fig. 8D) mice following CypD deletion.

In vitro evidence has led to the proposal that misfolded SOD1 protein is present as small soluble forms before coalesc- ing into large aggregates (Rakhit et al., 2004). To determine whether the reduction in misfolded SOD1 levels in CypDdeleted mutant SOD1 mice reflects a decrease in the accumulation of the soluble and/or aggregated misfolded SOD1, size exclusion chromatography was used to separate SOD1 forms from $\mathrm{CypD}^{+/+} / \mathrm{SOD} 1^{\mathrm{G} 93 \mathrm{~A}}$ or $\mathrm{CypD}^{-/-} / \mathrm{SOD} 1^{\mathrm{G} 93 \mathrm{~A}}$ spinal cords (Fig. $8 A$ ). In CypD ${ }^{+/+} /$SOD $1^{\text {G93A }}$ spinal cords SOD1 eluted in low molecular weight complexes $\sim 29 \mathrm{kDa}$ (corresponding to the soluble SOD1 dimers) and also in high molecular weight complexes from several hundred $\mathrm{kDa}$ to $2 \mathrm{MDa}$ (Fig. 8E). While SOD1 levels in the low molecular weight complexes $(<29 \mathrm{kDa})$ in $\mathrm{CypD}^{-1-} / \mathrm{SOD} 1^{\mathrm{G} 93 \mathrm{~A}}$ spinal cords were similar to (or slightly higher) than that for $\mathrm{CypD}^{+/+} /$ SOD1 ${ }^{\mathrm{G} 93 A}$, SOD1 levels in high molecular weight complexes were significantly diminished in CypD-deleted mutant SOD1 animals (Fig. 8E).

Since both high levels of cytosolic $\mathrm{Ca}^{2+}$ and increased oxidative damage may contribute to SOD1 aggregation (Beers et al., 2001; Kim et al., 2002; Rakhit et al., 2002; Tateno et al., 2004; Bosco et al., 2010), a plausible explanation is that the decrease in aggregated SOD 1 in the CypD ${ }^{-1-}$ nervous system arises from a combination of reduced oxygen radical production by $\mathrm{Ca}^{2+}$-mediated damage to mitochondria (Du et al., 2008) and a decrease in cytosolic levels of $\mathrm{Ca}^{2+}$ (Barsukova et al., 2011). In any event, deletion of CypD improves mitochondrial function and reduces both the overall level of misfolded SOD1 (including association with spinal cord mitochondria) and the accumulation of large aggregates within the spinal cord of misfolded SOD1 of different biochemical characteristics. 

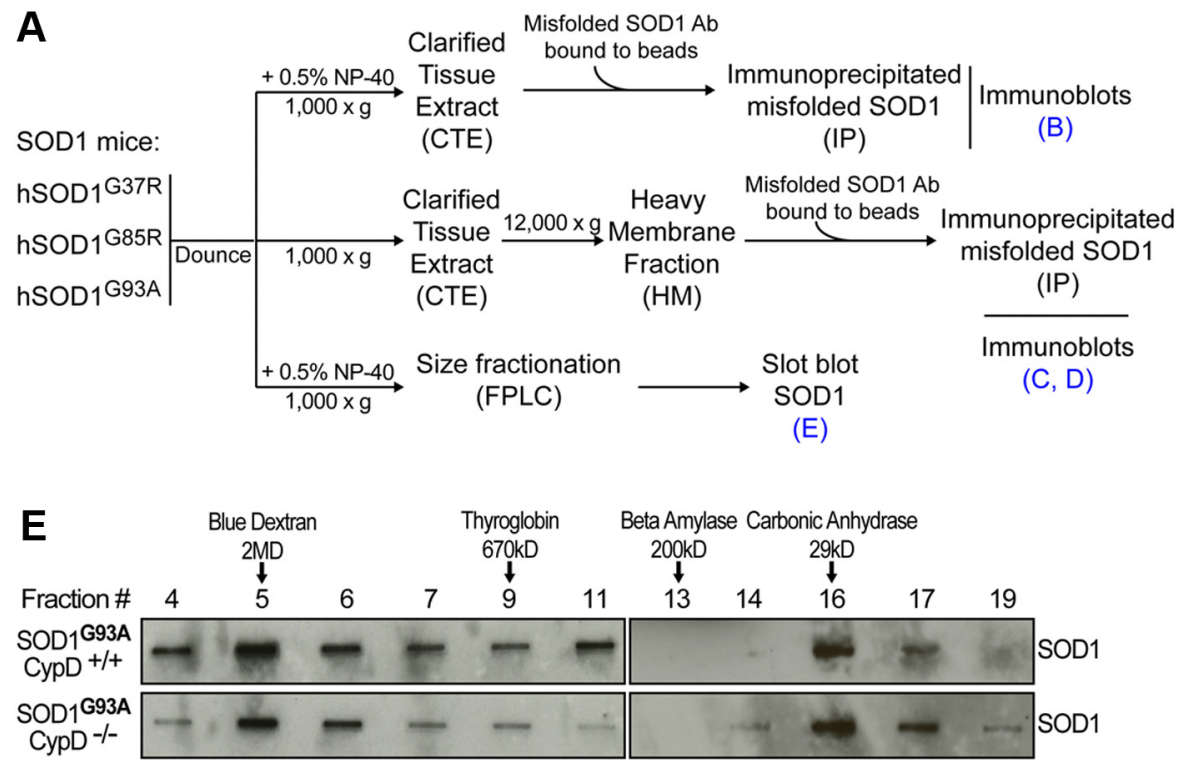

B
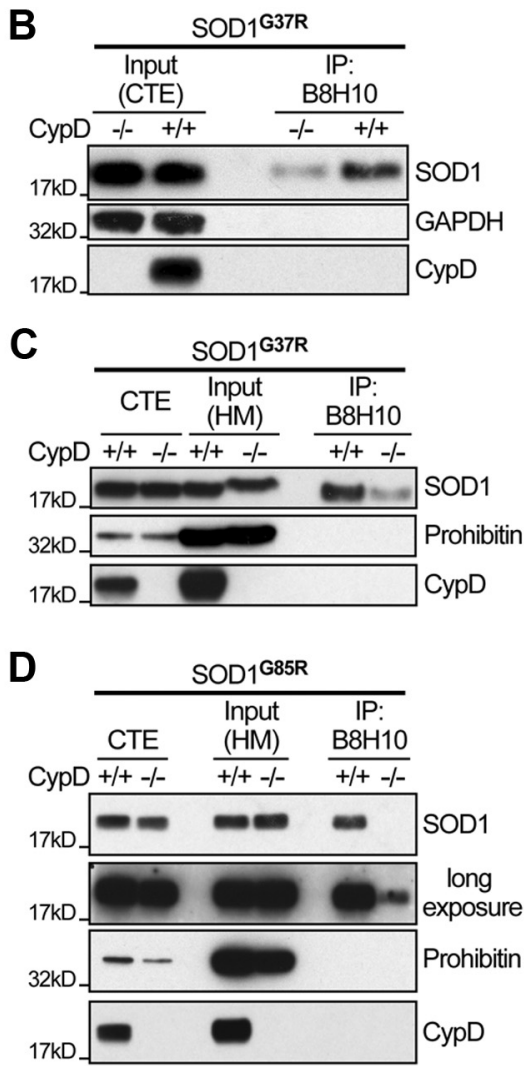

Figure 8. Improving mitochondrial function by deleting CypD in mutant SOD1 animals reduces the accumulation of misfolded SOD1 aggregates in whole spinal cord lysates and on the surface of spinal cord mitochondria. $\boldsymbol{A}$, Schematic outlining the different purification steps used. Whole spinal cord lysate (B) from CypD ${ }^{+/+}$or CypD ${ }^{-1-}$ mutant SOD1 mice or mitochondria-enriched heavy membrane fraction $(\boldsymbol{C}$, D) from spinal cords of CypD ${ }^{+/+}$or CypD ${ }^{-1-}$ mutant SOD1 mice were immunoprecipitated with an antibody specifically detecting misfolded forms of SOD1 (B8H10). Whole spinal cord lysate from CypD ${ }^{+/+}$ or $\mathrm{CypD}^{-/-}$mutant SOD1 mice was fractionated using size exclusion chromatography $(\boldsymbol{E}) \cdot \boldsymbol{B}$, Immunoblot of whole tissue extracts and the misfolded SOD1 immunoprecipitated from clarified spinal cord extract using the indicated antibodies. $C, D$, Immunoblot of the misfolded SOD1 immunoprecipitated from a heavy membrane fraction of spinal cords enriched in mitochondria. $\boldsymbol{E}$, Immunoblot of SOD1 containing fractions separated by size exclusion chromatography and resolved by slot blot from spinal cord homogenates of CypD ${ }^{+/+}$or CypD ${ }^{-/-}$mutant SOD1 mice. The molecular weight of each fraction was estimated from the separation of the indicated recombinant proteins.

Improving mitochondrial function by deleting CypD in animals expressing SOD1 mutants with different biochemical properties does not alter disease course

Disease onset and progression in cohorts of SOD $1^{\mathrm{G} 37 \mathrm{R}}$, SOD $1^{\text {G85R }}$, and SOD ${ }^{\text {G93A }}$ with CypD ${ }^{+/+}$or CypD ${ }^{-/-}(n \geq 22$ for each genotype in each cohort) were followed (all matings were congenic on a $\mathrm{C} 57 \mathrm{Bl} / 6$ background to eliminate confounding genetic influences). Despite (1) sustained improvement in mitochondrial function throughout disease, (2) attenuated motor neuron death, (3) reduced astrogliosis and microgliosis, and (4) suppression of aggregates of misfolded SOD 1 in $\mathrm{CypD}^{-1-}$ mice, there were no significant differences in age of disease onset, age of reaching a symptomatic stage, or survival compared with CypD $^{+/+}$mice (Fig. 9A-C). For example, for SOD $1{ }^{\text {G37R }}$ (Fig. 9B;

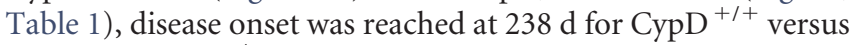
$241 \mathrm{~d}$ for CypD ${ }^{-1-}$ mice and survival was 397 versus $408 \mathrm{~d}$, respectively. For each mutant SOD1 line, the increased mitochondrial $\mathrm{Ca}^{2+}$ buffering by deletion of CypD provided no benefit to males and females alike (as demonstrated, for example, by segregating the animals in the SOD $1^{\mathrm{G} 93 \mathrm{~A}}$ cohort by sex; Table 1 ). Further, the gradual disease-related decrease in hindlimb muscle grip strength was also unaffected throughout disease despite sustained improvement of mitochondrial function upon CypD deletion in SOD $1^{\mathrm{G} 37 \mathrm{R}}, \mathrm{SOD} 1^{\mathrm{G} 85 \mathrm{R}}$, and SOD $1^{\mathrm{G} 93 \mathrm{~A}}$-expressing mice (Fig. 9D-F).

Altogether, despite improved mitochondrial function throughout disease by CypD deletion, disease course was unaffected in all three models of familial ALS from expression of ALS-linked SOD1 mutants of divergent biochemical character.

\section{Discussion}

We have established that desensitizing $\mathrm{Ca}^{2+}$-mediated mPTP opening in mutant SOD1-expressing mice rescues the loss of mitochondrial $\mathrm{Ca}^{2+}$ buffering capacity and ATP synthesis, reduces mitochondrial swelling in spinal cord motor neurons and mitochondrial damage in motor axons even at late stages of disease, and protects motor neurons against cell death in the three most widely used models of ALS-like disease in mice. Despite this, attenuating mitochondrial damage, reducing or eliminating motor neuron cell death, attenuating gliosis, and inhibiting aggregation of misfolded SOD1 in the spinal cord leaves disease course unaffected. Thus, the mitochondrial dysfunction(s) following $\mathrm{Ca}^{2+}$-mediated opening of the MPTP, the formation of large misfolded SOD1 aggregates, and motor neuron death cannot be central to the mechanism of progressive, paralytic disease. That attenuated motor neuron death provides no benefit in affecting disease course complements earlier evidence (Gould et al., 2006; Rouaux et al., 2007) in an aggressive early onset model of ALS from high levels of mutant SOD1, extending those findings to more slowly progressing disease from dismutase active or inactive mutant SOD1 accumulation at levels modestly above $\left(\mathrm{SOD} 1^{\mathrm{G} 37 \mathrm{R}}\right.$ ) or equal to (SOD1 ${ }^{\mathrm{G} 85 \mathrm{R}}$ ) those of the endogenous mouse protein, thus mimicking more closely the levels of mutant SOD1 accumulation in ALS patients. 

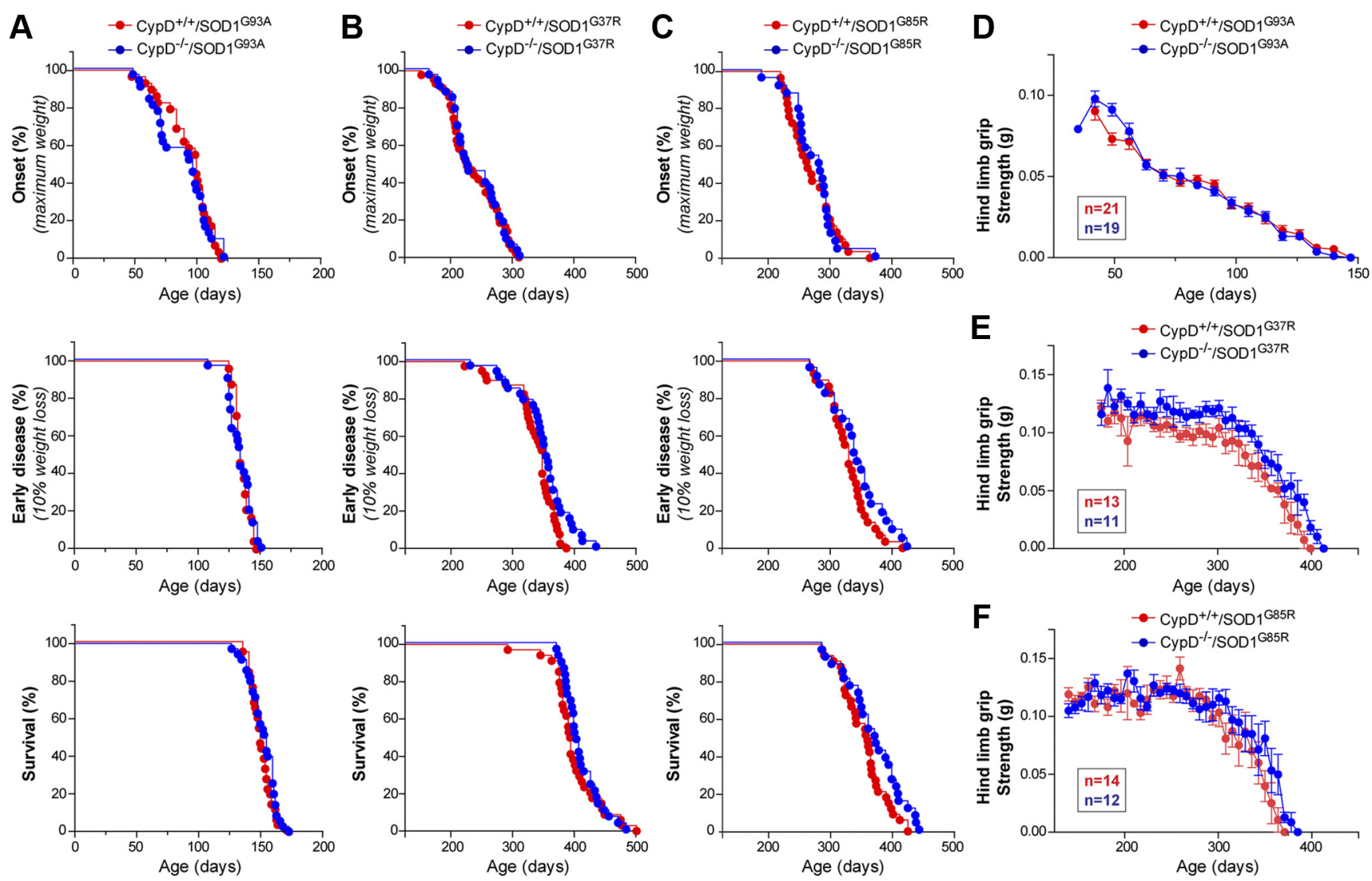

Figure 9. Improving mitochondrial function by deleting CypD in mutant SOD1 animals does not alter disease course. A-C, Plot of ages (in days) at which disease onset (as determined by the weight peaks. At onset animals do not display any obvious motor phenotype), symptomatic stage (as determined by $10 \%$ weight loss from onset. This disease stage is characterized by clear gait

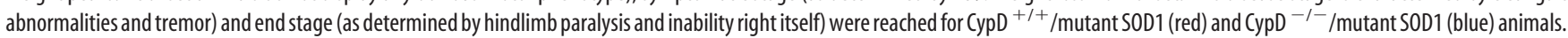
$\mathbf{D}-\boldsymbol{F}$, Plot of averaged grip strength for CypD ${ }^{+/+} /$mutant SOD1 (red) and CypD ${ }^{-/-} /$mutant SOD1 (blue) animals at indicated age.

Table 1. Ages of disease onset, reaching an early symptomatic stage and survival of mutant SOD1 mice in the presence or absence of CypD

\begin{tabular}{|c|c|c|c|c|c|c|c|c|c|c|}
\hline & \multicolumn{6}{|l|}{$\mathrm{SOD} 1^{\mathrm{G} 93 \mathrm{~A}}$} & \multicolumn{2}{|l|}{ SOD1 ${ }^{\text {G37R }}$} & \multirow{2}{*}{\multicolumn{2}{|c|}{$\begin{array}{l}\text { SOD1 }{ }^{\text {G85R }} \\
\text { Combined genders }\end{array}$}} \\
\hline & \multicolumn{2}{|l|}{ Combined genders } & \multicolumn{2}{|l|}{ Females } & \multicolumn{2}{|l|}{ Males } & \multicolumn{2}{|l|}{ Combined genders } & & \\
\hline & CypD $^{+1+}$ & CypD $^{-1-}$ & $\mathrm{CypD}^{+1+}$ & $\mathrm{CypD}^{-1-}$ & $\mathrm{CypD}^{+/+}$ & $\mathrm{CypD}^{-1-}$ & CypD $^{+1+}$ & $\mathrm{CypD}^{-1-}$ & CypD $^{+/+}$ & $\mathrm{CypD}^{-1-}$ \\
\hline Onset & $92 \pm 4(n=29)$ & $88 \pm 4(n=31)$ & $92 \pm 5(n=18)$ & $92 \pm 6(n=16)$ & $5(n=11)$ & $80 \pm 5(n=15)$ & $6(n=43)$ & $241 \pm 7(n=33)$ & $270 \pm 7(n=29)$ & $273 \pm 8(n=24)$ \\
\hline Early symptoms & $134 \pm 1(n=24)$ & $133 \pm 2(n=30)$ & $137 \pm 2(n=14)$ & $136 \pm 3(n=16)$ & $1(n=10)$ & $130 \pm 2(n=14)$ & $6(n=40)$ & $350 \pm 8(n=33)$ & $328 \pm 6(n=29)$ & $340 \pm 9(n=22)$ \\
\hline End stage & $149 \pm 1(n=37)$ & $150 \pm 2(n=35)$ & $152 \pm 2(n=20)$ & $154 \pm 2(n=17)$ & $146 \pm 2(n=17)$ & $147 \pm 2(n=18)$ & $397 \pm 6(n=35)$ & $408 \pm 5(n=29)$ & $355 \pm 6(n=33)$ & $369 \pm 9(n=26)$ \\
\hline
\end{tabular}

Values (days) are averages SEM.

Our findings also provide a mechanistic test of the proposal that $\mathrm{Ca}^{2+}$-induced opening of the MPTP is a key effector of axonal degeneration, a hypothesis that emerged in part from a report that reduced levels or pharmacological inhibition of CypD delayed the disintegration process (Wallerian degeneration) of the distal portion of an injured nerve in transected sciatic nerve explants (Barrientos et al., 2011). To this, not only have we and others shown that delaying Wallerian degeneration in SOD1 mutant models of ALS in mice (by introducing the "slow Wallerian degeneration" mutation $\mathrm{Wld}^{\mathrm{s}}$ ) does not (Vande Velde et al., 2004), or only modestly (Fischer et al., 2005), prolongs survival, our current evidence demonstrates no slowing of degeneration from improved $\mathrm{Ca}^{2+}$ buffering and delayed mPTP opening. Therefore, although opening of the mPTP upon $\mathrm{Ca}^{2+}$ overload may contribute to distal axonal degeneration following injury, it is unlikely to be a primary contributor to degeneration of motor axons in mouse models of familial ALS that develop adult-onset fatal paralysis.
The absence of effect on any aspect of disease course in both males and females following removal of CypD contrasts with claims from two previous studies (Martin et al., 2009; Kim et al., 2012) reporting noncongenic matings of $\mathrm{CypD}^{-1-}$ mice with mutant SOD1 ${ }^{\mathrm{G} 93 \mathrm{~A}}$ animals and which reported conflicting outcomes on how CypD deletion affected survival. While Martin et al. (2009) claimed a delay in disease onset, which was then accompanied by an unexplained doubling of the rate of disease progression, with effect sizes differing between males and females, Kim et al. (2012) reported a lack of effect in males with slight acceleration of disease in females. The divergent outcomes of these two reports (Martin et al., 2009; Kim et al., 2012) are likely to be attributable to confounding genetic changes in the CypD gene disruption mouse lines used in these earlier studies. The CypD $^{-1-}$ strain used by Martin et al. (2009) develops multiple disorders (cardiomegaly and lymphoma, as well as liver disease and ovarian cancer [L.J. Martin, personal communication]) that are not seen in the CypD deletion mouse line used here. The 
CypD ${ }^{+/+} / \mathrm{SOD} 1{ }^{\mathrm{G} 93 \mathrm{~A}}$ mice of the experimental cohort in the Kim et al. (2012) study lived $50 \mathrm{~d}$ longer than their $\mathrm{CypD}^{+/+} /$ SOD1 ${ }^{\mathrm{G} 93 \mathrm{~A}}$ parents, demonstrating (as the authors acknowledged) the presence of a confounding genetic contributor(s) other than the mutant SOD1 transgene or CypD alleles. In contrast, the common outcome from our efforts using congenic matings and all three of the most frequently used SOD1 mutant mouse models provides what we believe is a comprehensive test demonstrating that loss of mitochondrial $\mathrm{Ca}^{2+}$ capacity is not a primary contributor to disease course in mutant SOD1 mice.

Astroglial and microglial activation is a well accepted feature of ALS in both patients and ALS mice models (Engelhardt and Appel, 1990; Kushner et al., 1991; Wong et al., 1995; Bruijn et al., 1997; Alexianu et al., 2001; Howland et al., 2002; Henkel et al., 2004). In addition, decreased mitochondrial respiration and ATP synthesis, as well as increased mitochondrial oxygen radical production, have been reported in primary astrocytes isolated from SOD $1^{\mathrm{G} 93 \mathrm{~A}}$ mice (Cassina et al., 2008). This has suggested that glial activation may be linked to mitochondrial defects within those glia. Our results show that preventing mitochondrial damage in symptomatic mutant SOD1 mice decreases astroglial and microglial activation. Thus, these results suggest that mitochondrial damage mediated at least in part by $\mathrm{Ca}^{2+}$ induced mPTP opening may contribute to increased glial activation. Alternatively, the attenuation in glial activation that we observe in mutant SOD1 mice deleted in CypD may be due to the concomitant reduction in motor neuron cell death in these animals. This latter possibility is supported by evidence showing that glial activation is clearly increased only postsymptomatically in different mutant SOD1 mice mouse models (Wong et al., 1995; Bruijn et al., 1997; Hall et al., 1998; Levine et al., 1999). In addition, markers of glial activation were found to be significantly elevated in mice expressing high levels of mutant SOD1 selectively within motor neurons and which do not develop adult-onset fatal ALS-like paralysis but that sustain loss of motor neurons in late adulthood (Jaarsma et al., 2008). Importantly, our evidence of decreased GFAP and IbaI staining in CypD-deleted mutant SOD1 mice is fully consistent with the now well accepted proposal that mutant SOD1mediated toxicity within astrocytes and microglia is a central component of the mechanism of disease progression (Beers et al., 2006; Boillée et al., 2006b; Di Giorgio et al., 2007; Nagai et al., 2007; Yamanaka et al., 2008). Our results show, however, that elevated astrocytic and microglial activation in symptomatic mutant SOD1 animals is not an indicator of the component of disease mechanism produced by mutant SOD1 synthesis within glia.

The formation of mutant SOD1 aggregates during disease in the spinal cords of both ALS patients carrying mutations in SOD1 and in transgenic mouse models has been proposed by many investigators to contribute to mutant SOD1-mediated toxicity (Durham et al., 1997; Bruijn et al., 1998; Johnston et al., 2000; Shinder et al., 2001; Wang et al., 2002). The generation of antibodies binding to epitopes exposed only in non-natively folded forms of SOD1 has revealed that misfolded SOD1 conformers form aggregates in ALS patients and mutant SOD1 mice (Rakhit et al., 2007; Gros-Louis et al., 2010; Kerman et al., 2010; Grad et al., 2011). Our use of a combination of IP, size exclusion chromatography, and immunofluorescence with multiple antibodies recognizing disease-specific misfolded SOD1 conformers has established that aggregated, but not soluble, misfolded SOD1 is significantly reduced in symptomatic animals expressing any of three ALS-linked mutations of SOD1 and deleted in CypD. Since this is not accompanied by an alteration in disease course, misfolded SOD1 aggregates must be a consequence rather than a central component of initiating or propagating disease pathogenesis. In agreement with this, formation of the large misfolded SOD1 aggregates in the spinal cord is largely undetectable before the onset of neuromuscular denervation (Rakhit et al., 2007; Karch et al., 2009; Gros-Louis et al., 2010). Furthermore, we have shown that aggregated misfolded SOD1, scored with different misfolded SOD1-specific antibodies, accumulates at different levels in disease-matched SOD $1^{\mathrm{G} 37 \mathrm{R}}, \mathrm{SOD} 1^{\mathrm{G} 85 \mathrm{R}}$, and SOD $1^{\mathrm{G} 93 \mathrm{~A}}$ mice, adding further evidence against it as a component of disease mechanism.

Thus, the accumulated evidence supports the pool of soluble misfolded protein as a primary contributor to mutant SOD1 toxicity. This conclusion is consistent with passive and active immunization approaches aimed at neutralizing misfolded SOD1 species, which have reported that a reduction in the soluble pool of misfolded SOD1 [some of which is extracellular (Urushitani et al., 2006)] correlates with an increase in survival in mutant SOD1 ${ }^{\mathrm{G} 37 \mathrm{R}}$ and SOD1 ${ }^{\mathrm{G} 93 \mathrm{~A}}$ mice (Urushitani et al., 2006; GrosLouis et al., 2010; Liu et al., 2012). This insight brings SOD1mediated ALS in line with the situation in several other neurodegenerative diseases where large inclusions correlate poorly with either onset or severity of neurodegeneration (Gutekunst et al., 1999; Kirkitadze et al., 2002; Arrasate et al., 2004; Van Raamsdonk et al., 2005; Treusch et al., 2009). The misfolded molecules so produced may mediate toxicity by binding to and/or interfering with specific cellular pathways [including hyperactivation of AMPK metabolism (Lim et al., 2012), chronic activation of NADPH oxidase by binding to Rac 1 (Harraz et al., 2008), induction of endoplasmic reticulum stress (Kikuchi et al., 2006; Nishitoh et al., 2008; Saxena et al., 2009), and mitochondrial dysfunction including inhibition of the voltage-dependent anion channel (Israelson et al., 2010) and errors in mitochondrial trafficking (Vande Velde et al., 2011; Magrane et al., 2012)] and also through secretion into the extracellular space (Urushitani et al., 2006).

\section{References}

Alexianu ME, Kozovska M, Appel SH (2001) Immune reactivity in a mouse model of familial ALS correlates with disease progression. Neurology 57: 1282-1289. CrossRef Medline

Arrasate M, Mitra S, Schweitzer ES, Segal MR, Finkbeiner S (2004) Inclusion body formation reduces levels of mutant huntingtin and the risk of neuronal death. Nature 431:805-810. CrossRef Medline

Azzolin L, von Stockum S, Basso E, Petronilli V, Forte MA, Bernardi P (2010) The mitochondrial permeability transition from yeast to mammals. FEBS Lett 584:2504-2509. CrossRef Medline

Baines CP, Kaiser RA, Purcell NH, Blair NS, Osinska H, Hambleton MA, Brunskill EW, Sayen MR, Gottlieb RA, Dorn GW, Robbins J, Molkentin JD (2005) Loss of cyclophilin D reveals a critical role for mitochondrial permeability transition in cell death. Nature 434:658-662. CrossRef Medline

Barrientos SA, Martinez NW, Yoo S, Jara JS, Zamorano S, Hetz C, Twiss JL, Alvarez J, Court FA (2011) Axonal degeneration is mediated by the mitochondrial permeability transition pore. J Neurosci 31:966-978. CrossRef Medline

Barsukova A, Komarov A, Hajnóczky G, Bernardi P, Bourdette D, Forte M (2011) Activation of the mitochondrial permeability transition pore modulates $\mathrm{Ca} 2+$ responses to physiological stimuli in adult neurons. Eur J Neurosci 33:831-842. CrossRef Medline

Basso E, Fante L, Fowlkes J, Petronilli V, Forte MA, Bernardi P (2005) Properties of the permeability transition pore in mitochondria devoid of Cyclophilin D. J Biol Chem 280:18558-18561. CrossRef Medline

Beers DR, Ho BK, Siklós L, Alexianu ME, Mosier DR, Mohamed AH, Otsuka Y, Kozovska ME, McAlhany RE, Smith RG, Appel SH (2001) Parvalbumin overexpression alters immune-mediated increases in intracellular calcium, and delays disease onset in a transgenic model of familial amyotrophic lateral sclerosis. J Neurochem 79:499-509. Medline 
Beers DR, Henkel JS, Xiao Q, Zhao W, Wang J, Yen AA, Siklos L, McKercher SR, Appel SH (2006) Wild-type microglia extend survival in PU. 1 knock-out mice with familial amyotrophic lateral sclerosis. Proc Natl Acad Sci U S A 103:16021-16026. CrossRef Medline

Bergemalm D, Jonsson PA, Graffmo KS, Andersen PM, Brännström T, Rehnmark A, Marklund SL (2006) Overloading of stable and exclusion of unstable human superoxide dismutase-1 variants in mitochondria of murine amyotrophic lateral sclerosis models. J Neurosci 26:4147-4154. CrossRef Medline

Bernardi P (1999) Mitochondrial transport of cations: channels, exchangers, and permeability transition. Physiol Rev 79:1127-1155. Medline

Bernardi P, Krauskopf A, Basso E, Petronilli V, Blachly-Dyson E, Di Lisa F, Forte MA (2006) The mitochondrial permeability transition from in vitro artifact to disease target. FEBS J 273:2077-2099. CrossRef Medline

Boillée S, Vande Velde C, Cleveland DW (2006a) ALS: a disease of motor neurons and their non-neuronal neighbors. Neuron 52:39-59. CrossRef Medline

Boillée S, Yamanaka K, Lobsiger CS, Copeland NG, Jenkins NA, Kassiotis G, Kollias G, Cleveland DW (2006b) Onset and progression in inherited ALS determined by motor neurons and microglia. Science 312: 1389-1392. CrossRef Medline

Bosco DA, Morfini G, Karabacak NM, Song Y, Gros-Louis F, Pasinelli P, Goolsby H, Fontaine BA, Lemay N, McKenna-Yasek D, Frosch MP, Agar JN, Julien JP, Brady ST, Brown RH Jr (2010) Wild-type and mutant SOD1 share an aberrant conformation and a common pathogenic pathway in ALS. Nat Neurosci 13:1396-1403. CrossRef Medline

Bruijn LI, Becher MW, Lee MK, Anderson KL, Jenkins NA, Copeland NG, Sisodia SS, Rothstein JD, Borchelt DR, Price DL, Cleveland DW (1997) ALS-linked SOD1 mutant G85R mediates damage to astrocytes and promotes rapidly progressive disease with SOD 1-containing inclusions. Neuron 18:327-338. CrossRef Medline

Bruijn LI, Houseweart MK, Kato S, Anderson KL, Anderson SD, Ohama E, Reaume AG, Scott RW, Cleveland DW (1998) Aggregation and motor neuron toxicity of an ALS-linked SOD1 mutant independent from wildtype SOD1. Science 281:1851-1854. CrossRef Medline

Cassina P, Cassina A, Pehar M, Castellanos R, Gandelman M, de León A, Robinson KM, Mason RP, Beckman JS, Barbeito L, Radi R (2008) Mitochondrial dysfunction in SOD1G93A-bearing astrocytes promotes motor neuron degeneration: prevention by mitochondrial-targeted antioxidants. J Neurosci 28:4115-4122. CrossRef Medline

Damiano M, Starkov AA, Petri S, Kipiani K, Kiaei M, Mattiazzi M, Flint Beal M, Manfredi G (2006) Neural mitochondrial Ca2 + capacity impairment precedes the onset of motor symptoms in G93A Cu/Zn-superoxide dismutase mutant mice. J Neurochem 96:1349-1361. CrossRef Medline

Deng HX, Hentati A, Tainer JA, Iqbal Z, Cayabyab A, Hung WY, Getzoff ED, Hu P, Herzfeldt B, Roos RP (1993) Amyotrophic lateral sclerosis and structural defects in $\mathrm{Cu}, \mathrm{Zn}$ superoxide dismutase. Science 261: 1047-1051. CrossRef Medline

Deng HX, Shi Y, Furukawa Y, Zhai H, Fu R, Liu E, Gorrie GH, Khan MS, Hung WY, Bigio EH, Lukas T, Dal Canto MC, O'Halloran TV, Siddique T (2006) Conversion to the amyotrophic lateral sclerosis phenotype is associated with intermolecular linked insoluble aggregates of SOD1 in mitochondria. Proc Natl Acad Sci U S A 103:7142-7147. CrossRef Medline

Di Giorgio FP, Carrasco MA, Siao MC, Maniatis T, Eggan K (2007) Noncell autonomous effect of glia on motor neurons in an embryonic stem cellbased ALS model. Nat Neurosci 10:608-614. CrossRef Medline

Du H, Guo L, Fang F, Chen D, Sosunov AA, McKhann GM, Yan Y, Wang C, Zhang H, Molkentin JD, Gunn-Moore FJ, Vonsattel JP, Arancio O, Chen JX, Yan SD (2008) Cyclophilin D deficiency attenuates mitochondrial and neuronal perturbation and ameliorates learning and memory in Alzheimer's disease. Nat Med 14:1097-1105. CrossRef Medline

Durham HD, Roy J, Dong L, Figlewicz DA (1997) Aggregation of mutant $\mathrm{Cu} / \mathrm{Zn}$ superoxide dismutase proteins in a culture model of ALS. J Neuropathol Exp Neurol 56:523-530. CrossRef Medline

Engelhardt JI, Appel SH (1990) IgG reactivity in the spinal cord and motor cortex in amyotrophic lateral sclerosis. Arch Neurol 47:1210-1216. CrossRef Medline

Fischer LR, Culver DG, Davis AA, Tennant P, Wang M, Coleman M, Asress S, Adalbert R, Alexander GM, Glass JD (2005) The WldS gene modestly prolongs survival in the SOD1G93A fALS mouse. Neurobiol Dis 19:293300. CrossRef Medline

Gould TW, Buss RR, Vinsant S, Prevette D, Sun W, Knudson CM, Milligan
CE, Oppenheim RW (2006) Complete dissociation of motor neuron death from motor dysfunction by Bax deletion in a mouse model of ALS. J Neurosci 26:8774-8786. CrossRef Medline

Grad LI, Guest WC, Yanai A, Pokrishevsky E, O’Neill MA, Gibbs E, Semenchenko V, Yousefi M, Wishart DS, Plotkin SS, Cashman NR (2011) Intermolecular transmission of superoxide dismutase 1 misfolding in living cells. Proc Natl Acad Sci U S A 108:16398-16403. CrossRef Medline

Gros-Louis F, Soucy G, Larivière R, Julien JP (2010) Intracerebroventricular infusion of monoclonal antibody or its derived Fab fragment against misfolded forms of SOD1 mutant delays mortality in a mouse model of ALS. J Neurochem 113:1188-1199. Medline

Gurney ME, Pu H, Chiu AY, Dal Canto MC, Polchow CY, Alexander DD, Caliendo J, Hentati A, Kwon YW, Deng HX (1994) Motor neuron degeneration in mice that express a human $\mathrm{Cu}, \mathrm{Zn}$ superoxide dismutase mutation. Science 264:1772-1775. CrossRef Medline

Gutekunst CA, Li SH, Yi H, Mulroy JS, Kuemmerle S, Jones R, Rye D, Ferrante RJ, Hersch SM, Li XJ (1999) Nuclear and neuropil aggregates in Huntington's disease: relationship to neuropathology. J Neurosci 19:2522-2534. Medline

Hall ED, Oostveen JA, Gurney ME (1998) Relationship of microglial and astrocytic activation to disease onset and progression in a transgenic model of familial ALS. Glia 23:249-256. CrossRef Medline

Harraz MM, Marden JJ, Zhou W, Zhang Y, Williams A, Sharov VS, Nelson K, Luo M, Paulson H, Schöneich C, Engelhardt JF (2008) SOD1 mutations disrupt redox-sensitive Rac regulation of NADPH oxidase in a familial ALS model. J Clin Invest 118:659-670. Medline

Henkel JS, Engelhardt JI, Siklós L, Simpson EP, Kim SH, Pan T, Goodman JC, Siddique T, Beers DR, Appel SH (2004) Presence of dendritic cells, MCP-1, and activated microglia/macrophages in amyotrophic lateral sclerosis spinal cord tissue. Ann Neurol 55:221-235. CrossRef Medline

Howland DS, Liu J, She Y, Goad B, Maragakis NJ, Kim B, Erickson J, Kulik J, DeVito L, Psaltis G, DeGennaro LJ, Cleveland DW, Rothstein JD (2002) Focal loss of the glutamate transporter EAAT2 in a transgenic rat model of SOD1 mutant-mediated amyotrophic lateral sclerosis (ALS). Proc Natl Acad Sci U S A 99:1604-1609. CrossRef Medline

Hunter DR, Haworth RA (1979) The Ca2+-induced membrane transition in mitochondria. I. The protective mechanisms. Arch Biochem Biophys 195:453-459. CrossRef Medline

Ilieva H, Polymenidou M, Cleveland DW (2009) Non-cell autonomous toxicity in neurodegenerative disorders: ALS and beyond. J Cell Biol 187: 761-772. CrossRef Medline

Israelson A, Arbel N, Da Cruz S, Ilieva H, Yamanaka K, Shoshan-Barmatz V, Cleveland DW (2010) Misfolded mutant SOD1 directly inhibits VDAC1 conductance in a mouse model of inherited ALS. Neuron 67:575587. CrossRef Medline

Jaarsma D, Teuling E, Haasdijk ED, De Zeeuw CI, Hoogenraad CC (2008) Neuron-specific expression of mutant superoxide dismutase is sufficient to induce amyotrophic lateral sclerosis in transgenic mice. J Neurosci 28:2075-2088. CrossRef Medline

Jaiswal MK, Keller BU (2009) Cu/Zn superoxide dismutase typical for familial amyotrophic lateral sclerosis increases the vulnerability of mitochondria and perturbs $\mathrm{Ca} 2+$ homeostasis in SOD1G93A mice. Mol Pharmacol 75:478-489. CrossRef Medline

Johnston JA, Dalton MJ, Gurney ME, Kopito RR (2000) Formation of high molecular weight complexes of mutant $\mathrm{Cu}, \mathrm{Zn}$-superoxide dismutase in a mouse model for familial amyotrophic lateral sclerosis. Proc Natl Acad Sci U S A 97:12571-12576. CrossRef Medline

Karch CM, Prudencio M, Winkler DD, Hart PJ, Borchelt DR (2009) Role of mutant SOD1 disulfide oxidation and aggregation in the pathogenesis of familial ALS. Proc Natl Acad Sci U S A 106:7774-7779. CrossRef Medline

Kawamata H, Manfredi G (2010) Mitochondrial dysfunction and intracellular calcium dysregulation in ALS. Mech Ageing Dev 131:517-526. CrossRef Medline

Kerman A, Liu HN, Croul S, Bilbao J, Rogaeva E, Zinman L, Robertson J, Chakrabartty A (2010) Amyotrophic lateral sclerosis is a nonamyloid disease in which extensive misfolding of SOD1 is unique to the familial form. Acta Neuropathol 119:335-344. CrossRef Medline

Kikuchi H, Almer G, Yamashita S, Guégan C, Nagai M, Xu Z, Sosunov AA, McKhann GM 2nd, Przedborski S (2006) Spinal cord endoplasmic reticulum stress associated with a microsomal accumulation of mutant superoxide dismutase-1 in an ALS model. Proc Natl Acad Sci U S A 103: 6025-6030. CrossRef Medline 
Kim HJ, Kim M, Kim SH, Sung JJ, Lee KW (2002) Alteration in intracellular calcium homeostasis reduces motor neuronal viability expressing mutated $\mathrm{Cu} / \mathrm{Zn}$ superoxide dismutase through a nitric oxide/guanylyl cyclase cGMP cascade. Neuroreport 13:1131-1135. CrossRef Medline

Kim HJ, Magran è J, Starkov AA, Manfredi G (2012) The mitochondrial calcium regulator cyclophilin D is an essential component of oestrogenmediated neuroprotection in amyotrophic lateral sclerosis. Brain 135: 2865-2874. CrossRef Medline

Kirkitadze MD, Bitan G, Teplow DB (2002) Paradigm shifts in Alzheimer's disease and other neurodegenerative disorders: the emerging role of oligomeric assemblies. J Neurosci Res 69:567-577. CrossRef Medline

Kushner PD, Stephenson DT, Wright S (1991) Reactive astrogliosis is widespread in the subcortical white matter of amyotrophic lateral sclerosis brain. J Neuropathol Exp Neurol 50:263-277. CrossRef Medline

Levine JB, Kong J, Nadler M, Xu Z (1999) Astrocytes interact intimately with degenerating motor neurons in mouse amyotrophic lateral sclerosis (ALS). Glia 28:215-224. CrossRef Medline

Li Q, Vande Velde C, Israelson A, Xie J, Bailey AO, Dong MQ, Chun SJ, Roy T, Winer L, Yates JR, Capaldi RA, Cleveland DW, Miller TM (2010) ALS-linked mutant superoxide dismutase 1 (SOD1) alters mitochondrial protein composition and decreases protein import. Proc Natl Acad Sci U S A 107:21146-21151. CrossRef Medline

Lim MA, Selak MA, Xiang Z, Krainc D, Neve RL, Kraemer BC, Watts JL, Kalb RG (2012) Reduced activity of AMP-activated protein kinase protects against genetic models of motor neuron disease. J Neurosci 32:1123-1141. CrossRef Medline

Liu HN, Tjostheim S, Dasilva K, Taylor D, Zhao B, Rakhit R, Brown M, Chakrabartty A, McLaurin J, Robertson J (2012) Targeting of mono$\mathrm{mer} / \mathrm{misfolded} \mathrm{SOD1}$ as a therapeutic strategy for amyotrophic lateral sclerosis. J Neurosci 32:8791-8799. CrossRef Medline

Liu J, Lillo C, Jonsson PA, Vande Velde C, Ward CM, Miller TM, Subramaniam JR, Rothstein JD, Marklund S, Andersen PM, Brännström T, Gredal O, Wong PC, Williams DS, Cleveland DW (2004) Toxicity of familial ALS-linked SOD1 mutants from selective recruitment to spinal mitochondria. Neuron 43:5-17. CrossRef Medline

Liu J, Shinobu LA, Ward CM, Young D, Cleveland DW (2005) Elevation of the Hsp70 chaperone does not effect toxicity in mouse models of familial amyotrophic lateral sclerosis. J Neurochem 93:875-882. CrossRef Medline

Lobsiger CS, Boillee S, McAlonis-Downes M, Khan AM, Feltri ML, Yamanaka K, Cleveland DW (2009) Schwann cells expressing dismutase active mutant SOD1 unexpectedly slow disease progression in ALS mice. Proc Natl Acad Sci U S A 106:4465-4470. CrossRef Medline

Magran é J, Sahawneh MA, Przedborski S, Estévez ÁG, Manfredi G (2012) Mitochondrial dynamics and bioenergetic dysfunction is associated with synaptic alterations in mutant SOD1 motor neurons. J Neurosci 32:229-242. CrossRef Medline

Martin LJ, Gertz B, Pan Y, Price AC, Molkentin JD, Chang Q (2009) The mitochondrial permeability transition pore in motor neurons: involvement in the pathobiology of ALS mice. Exp Neurol 218:333-346. CrossRef Medline

Matsumoto A, Okada Y, Nakamichi M, Nakamura M, Toyama Y, Sobue G, Nagai M, Aoki M, Itoyama Y, Okano H (2006) Disease progression of human SOD1 (G93A) transgenic ALS model rats. J Neurosci Res 83:119133. CrossRef Medline

Mattiazzi M, D’Aurelio M, Gajewski CD, Martushova K, Kiaei M, Beal MF, Manfredi G (2002) Mutated human SOD1 causes dysfunction of oxidative phosphorylation in mitochondria of transgenic mice. J Biol Chem 277:29626-29633. CrossRef Medline

Nagai M, Re DB, Nagata T, Chalazonitis A, Jessell TM, Wichterle H, Przedborski S (2007) Astrocytes expressing ALS-linked mutated SOD1 release factors selectively toxic to motor neurons. Nat Neurosci 10:615-622. CrossRef Medline

Nakagawa T, Shimizu S, Watanabe T, Yamaguchi O, Otsu K, Yamagata H, Inohara H, Kubo T, Tsujimoto Y (2005) Cyclophilin D-dependent mitochondrial permeability transition regulates some necrotic but not apoptotic cell death. Nature 434:652-658. CrossRef Medline

Nicholls DG (2009) Mitochondrial calcium function and dysfunction in the central nervous system. Biochim Biophys Acta 1787:1416-1424. CrossRef Medline

Nishitoh H, Kadowaki H, Nagai A, Maruyama T, Yokota T, Fukutomi H, Noguchi T, Matsuzawa A, Takeda K, Ichijo H (2008) ALS-linked mu- tant SOD1 induces ER stress- and ASK1-dependent motor neuron death by targeting Derlin-1. Genes Dev 22:1451-1464. CrossRef Medline

Pedrini S, Sau D, Guareschi S, Bogush M, Brown RH Jr, Naniche N, Kia A, Trotti D, Pasinelli P (2010) ALS-linked mutant SOD1 damages mitochondria by promoting conformational changes in Bcl-2. Hum Mol Genet 19:2974-2986. CrossRef Medline

Petronilli V, Penzo D, Scorrano L, Bernardi P, Di Lisa F (2001) The mitochondrial permeability transition, release of cytochrome $\mathrm{c}$ and cell death. Correlation with the duration of pore openings in situ. J Biol Chem 276: 12030-12034. CrossRef Medline

Pickles S, Vande Velde C (2012) Misfolded SOD1 and ALS: zeroing in on mitochondria. Amyotroph Lateral Scler 13:333-340. CrossRef Medline

Rakhit R, Cunningham P, Furtos-Matei A, Dahan S, Qi XF, Crow JP, Cashman NR, Kondejewski LH, Chakrabartty A (2002) Oxidation-induced misfolding and aggregation of superoxide dismutase and its implications for amyotrophic lateral sclerosis. J Biol Chem 277:47551-47556. CrossRef Medline

Rakhit R, Crow JP, Lepock JR, Kondejewski LH, Cashman NR, Chakrabartty A (2004) Monomeric $\mathrm{Cu}, \mathrm{Zn}$-superoxide dismutase is a common misfolding intermediate in the oxidation models of sporadic and familial amyotrophic lateral sclerosis. J Biol Chem 279:15499-15504. CrossRef Medline

Rakhit R, Robertson J, Vande Velde C, Horne P, Ruth DM, Griffin J, Cleveland DW, Cashman NR, Chakrabartty A (2007) An immunological epitope selective for pathological monomer-misfolded SOD1 in ALS. Nat Med 13:754-759. CrossRef Medline

Rosen DR, Siddique T, Patterson D, Figlewicz DA, Sapp P, Hentati A, Donaldson D, Goto J, O'Regan JP, Deng HX (1993) Mutations in Cu/Zn superoxide dismutase gene are associated with familial amyotrophic lateral sclerosis. Nature 362:59-62. CrossRef Medline

Rothstein JD, Tsai G, Kuncl RW, Clawson L, Cornblath DR, Drachman DB, Pestronk A, Stauch BL, Coyle JT (1990) Abnormal excitatory amino acid metabolism in amyotrophic lateral sclerosis. Ann Neurol 28:18-25. CrossRef Medline

Rothstein JD, Martin LJ, Kuncl RW (1992) Decreased glutamate transport by the brain and spinal cord in amyotrophic lateral sclerosis. $\mathrm{N}$ Engl J Med 326:1464-1468. CrossRef Medline

Rouaux C, Panteleeva I, Ren é F, Gonzalez de Aguilar JL, Echaniz-Laguna A, Dupuis L, Menger Y, Boutillier AL, Loeffler JP (2007) Sodium valproate exerts neuroprotective effects in vivo through CREB-binding proteindependent mechanisms but does not improve survival in an amyotrophic lateral sclerosis mouse model. J Neurosci 27:5535-5545. CrossRef Medline

Roy J, Minotti S, Dong L, Figlewicz DA, Durham HD (1998) Glutamate potentiates the toxicity of mutant $\mathrm{Cu} / \mathrm{Zn}$-superoxide dismutase in motor neurons by postsynaptic calcium-dependent mechanisms. J Neurosci 18: 9673-9684. Medline

Saxena S, Cabuy E, Caroni P (2009) A role for motoneuron subtypeselective ER stress in disease manifestations of FALS mice. Nat Neurosci 12:627-636. CrossRef Medline

Schinzel AC, Takeuchi O, Huang Z, Fisher JK, Zhou Z, Rubens J, Hetz C, Danial NN, Moskowitz MA, Korsmeyer SJ (2005) Cyclophilin D is a component of mitochondrial permeability transition and mediates neuronal cell death after focal cerebral ischemia. Proc Natl Acad Sci U S A 102:12005-12010. CrossRef Medline

Schütz B, Reimann J, Dumitrescu-Ozimek L, Kappes-Horn K, Landreth GE, Schürmann B, Zimmer A, Heneka MT (2005) The oral antidiabetic pioglitazone protects from neurodegeneration and amyotrophic lateral sclerosis-like symptoms in superoxide dismutase-G93A transgenic mice. J Neurosci 25:7805-7812. CrossRef Medline

Shinder GA, Lacourse MC, Minotti S, Durham HD (2001) Mutant Cu/Znsuperoxide dismutase proteins have altered solubility and interact with heat shock/stress proteins in models of amyotrophic lateral sclerosis. J Biol Chem 276:12791-12796. CrossRef Medline

Siklós L, Engelhardt J, Harati Y, Smith RG, Jo ó F, Appel SH (1996) Ultrastructural evidence for altered calcium in motor nerve terminals in amyotrophic lateral sclerosis. Ann Neurol 39:203-216. CrossRef Medline

Siklós L, Engelhardt JI, Alexianu ME, Gurney ME, Siddique T, Appel SH (1998) Intracellular calcium parallels motoneuron degeneration in SOD-1 mutant mice. J Neuropathol Exp Neurol 57:571-587. CrossRef Medline

Tateno M, Sadakata H, Tanaka M, Itohara S, Shin RM, Miura M, Masuda M, 
Aosaki T, Urushitani M, Misawa H, Takahashi R (2004) Calciumpermeable AMPA receptors promote misfolding of mutant SOD1 protein and development of amyotrophic lateral sclerosis in a transgenic mouse model. Hum Mol Genet 13:2183-2196. CrossRef Medline

Treusch S, Cyr DM, Lindquist S (2009) Amyloid deposits: protection against toxic protein species? Cell Cycle 8:1668-1674. CrossRef Medline

Urushitani M, Sik A, Sakurai T, Nukina N, Takahashi R, Julien JP (2006) Chromogranin-mediated secretion of mutant superoxide dismutase proteins linked to amyotrophic lateral sclerosis. Nat Neurosci 9:108-118. CrossRef Medline

Van Damme P, Leyssen M, Callewaert G, Robberecht W, Van Den Bosch L (2003) The AMPA receptor antagonist NBQX prolongs survival in a transgenic mouse model of amyotrophic lateral sclerosis. Neurosci Lett 343:81-84. CrossRef Medline

Van Den Bosch L, Van Damme P, Bogaert E, Robberecht W (2006) The role of excitotoxicity in the pathogenesis of amyotrophic lateral sclerosis. Biochim Biophys Acta 1762:1068-1082. CrossRef Medline

Van Raamsdonk JM, Murphy Z, Slow EJ, Leavitt BR, Hayden MR (2005) Selective degeneration and nuclear localization of mutant huntingtin in the YAC128 mouse model of Huntington disease. Hum Mol Genet 14: 3823-3835. CrossRef Medline

Vande Velde C, Garcia ML, Yin X, Trapp BD, Cleveland DW (2004) The neuroprotective factor Wlds does not attenuate mutant SOD1-mediated motor neuron disease. Neuromolecular Med 5:193-203. CrossRef Medline

Vande Velde C, Miller TM, Cashman NR, Cleveland DW (2008) Selective association of misfolded ALS-linked mutant SOD1 with the cytoplasmic face of mitochondria. Proc Natl Acad Sci U S A 105:4022-4027. CrossRef Medline

Vande Velde C, McDonald KK, Boukhedimi Y, McAlonis-Downes M, Lobsiger CS, Bel Hadj S, Zandona A, Julien JP, Shah SB, Cleveland DW (2011) Misfolded SOD1 associated with motor neuron mitochondria alters mitochondrial shape and distribution prior to clinical onset. PloS One 6:e22031. CrossRef Medline

Vijayvergiya C, Beal MF, Buck J, Manfredi G (2005) Mutant superoxide dismutase 1 forms aggregates in the brain mitochondrial matrix of amyotrophic lateral sclerosis mice. J Neurosci 25:2463-2470. CrossRef Medline

von Lewinski F, Fuchs J, Vanselow BK, Keller BU (2008) Low Ca2+ buffering in hypoglossal motoneurons of mutant SOD1 (G93A) mice. Neurosci Lett 445:224-228. CrossRef Medline

Wang J, Xu G, Gonzales V, Coonfield M, Fromholt D, Copeland NG, Jenkins NA, Borchelt DR (2002) Fibrillar inclusions and motor neuron degeneration in transgenic mice expressing superoxide dismutase 1 with a disrupted copper-binding site. Neurobiol Dis 10:128-138. CrossRef Medline

Wong PC, Pardo CA, Borchelt DR, Lee MK, Copeland NG, Jenkins NA, Sisodia SS, Cleveland DW, Price DL (1995) An adverse property of a familial ALS-linked SOD1 mutation causes motor neuron disease characterized by vacuolar degeneration of mitochondria. Neuron 14: 1105-1116. CrossRef Medline

Yamanaka K, Chun SJ, Boillee S, Fujimori-Tonou N, Yamashita H, Gutmann DH, Takahashi R, Misawa H, Cleveland DW (2008) Astrocytes as determinants of disease progression in inherited amyotrophic lateral sclerosis. Nat Neurosci 11:251-253. CrossRef Medline 